\title{
Receptor tyrosine kinase, RON, promotes tumor progression by regulating EMT and the MAPK signaling pathway in human oral squamous cell carcinoma
}

\author{
SUN-AE KIM ${ }^{1,2}$, KYUNG-HWA LEE ${ }^{3}$, DONG HOON LEE ${ }^{1}$, JOON KYOO LEE ${ }^{1}$, SANG CHUL LIM $^{1}$, \\ YOUNG-EUN JOO ${ }^{4}$, IK-JOO CHUNG ${ }^{4}$, MYUNG-GIUN NOH $^{5}$ and TAE MI YOON ${ }^{1,2}$ \\ ${ }^{1}$ Department of Otorhinolaryngology-Head and Neck Surgery, ${ }^{2}$ Research Institute of Medical Sciences, \\ Chonnam National University, Departments of ${ }^{3}$ Pathology and ${ }^{4}$ Internal Medicine, \\ Chonnam National University Medical School and Hwasun Hospital, Hwasun, Chonnam 58128; \\ ${ }^{5}$ Department of Genomic Medicine, Gwangju Institute of Science and \\ Technology, Gwangju, Gwangju 61005, Republic of Korea
}

Received January 2, 2019; Accepted June 18, 2019

DOI: $10.3892 /$ ijo.2019.4836

\begin{abstract}
The receptor tyrosine kinase, recepteur d'origine nantais ( $\mathrm{RON}$ ), is known to be associated with the progression, metastasis, and prognosis of various types of cancers. Nevertheless, the role of RON in human oral squamous cell carcinoma (OSCC) is unclear. This study evaluated whether RON affects oncogenic behavior, oncogenic signaling pathways, and clinical outcomes, including survival, in human OSCC. Reverse transcription-PCR, quantitative PCR, western blotting and immunohistochemical staining were used to determine mRNA and protein expression levels of RON. Cell invasion, migration and apoptosis assays were used to assess the functional effects of small interfering RNA-mediated knockdown of RON or snail family transcriptional repressor 2 (SLUG). RON knockdown suppressed tumor cell invasion and migration and enhanced apoptosis in human OSCC cells. RON knockdown also decreased the phosphorylation of MAPK signaling proteins, such as ERK1/2, JNK and p38. In addition, RON knockdown suppressed the expression of the epithelial mesenchymal transition (EMT)-related transcription factor, SLUG. SLUG knockdown blocked the enhancement of cell invasion and migration induced by macrophage-stimulation protein (MSP)-mediated RON activation in OSCC cells. The cell morphology was changed to spindle-like shape under MSP-mediated RON activation in OSCC cells. RON was
\end{abstract}

Correspondence to: Professor Tae Mi Yoon, Department of Otorhinolaryngology-Head and Neck Surgery, Chonnam National University Medical School and Hwasun Hospital, 322 Seoyang-Ro, Hwasun, Chonnam 58128, Republic of Korea

E-mail: yoontm@chonnam.ac.kr

Key words: recepteur d'origine nantais protein, apoptosis, epithelial-mesenchymal transition, molecular targeted therapy, oral cancer overexpressed in both fresh and paraffin-embedded human OSCC tissues. Taken together, these results indicate that RON contributed to tumor progression by regulating the EMT-related factor, SLUG, and the MAPK pathway in OSCC. This study may provide a theoretical basis for the application of RON-targeting agents, currently being studied in various cancer fields, for the treatment of OSCC.

\section{Introduction}

Oral cancer is the 11th most prevalent cancer worldwide and the 3rd most common cancer in developing nations $(1,2)$. Squamous cell carcinoma represents $\sim 90 \%$ of oral cancer cases. The standard treatment strategies for patients with resectable advanced-stage oral squamous cell carcinoma (OSCC) are surgery following adjuvant radiotherapy or concurrent chemoradiotherapy (3). Although significant technological advances in the diagnosis and treatment of patients with OSCC have been made in last few decades, prognosis remains poor, with a 5-year overall survival rate of 50-60\%, becoming even lower in advanced stages (2). OSCC frequently leads to lymphatic metastasis, which is associated with the depth of invasion of the primary tumor. This represents the most important predictor of survival in patients with OSCC and has led to a major change in the $\mathrm{T}$ stage classification described in the 8th edition of the American Joint Committee on Cancer (4,5). The revised staging system now reflects not only tumor size, but also the depth of invasion (4). Therefore, in order to provide more effective treatment for patients with OSCC and to improve their clinical outcomes, an increased understanding of the molecular and biological mechanisms of tumor invasion and metastasis in OSCC is required.

The receptor tyrosine kinase, recepteur d'origine nantais (RON), also known as macrophage-stimulating 1 receptor (MST1R), is a member of the MET proto-oncogene family that includes c-Met (6). RON is activated by the ligand macrophage-stimulation protein (MSP) (7), and it has essential functional roles during embryonic development 
and organogenesis $(8,9)$. As with other proteins involved in embryonic development, RON is associated with carcinogenesis, cancer progression and metastasis. RON is overexpressed in various cancers and its overexpression is associated with poor prognosis in several types of cancer (10-18). Thus, RON has received much interest in the fields of cancer biology and cancer therapy targets over the past 20 years. Agents targeting RON and/or c-Met for cancer therapy, such as low molecular weight kinase inhibitors or monoclonal antibodies that neutralize the receptors or ligands, are in various phases of clinical trials and/or preclinical testing (19-21). Nevertheless, little is known about the role of RON in human OSCC.

The present study assessed whether RON affects aggressive cancer cell behaviors of human OSCC cells, such as invasion, migration and apoptosis inhibition and the oncogenic signaling pathways involved in these changes, including epithelial-mesenchymal transition and mitogen-activated protein kinase (MAPK) signaling pathways. The expression of RON in human OSCC tissues was analyzed by immunohistochemistry and reverse transcription-quantitative PCR (RT-qPCR). The potential association between RON expression and various clinicopathological variables, including survival, was evaluated in a well-defined series of OSCCs with complete long-term follow-up data. This study may provide an important basis for the application of new RON-targeting therapies for the treatment of OSCC.

\section{Materials and methods}

Cell culture and transfection. The human OSCC cell line, $\mathrm{SCC} 25$, was purchased from the American Type Culture Collection and the human OSCC cell line, PCI50, was provided by Dr Sung (Seoul National University, Seoul, South Korea). SCC25 cells were cultured in DMEM/F12 medium (Gibco; Thermo Fisher Scientific, Inc.) and PCI50 cells were cultured in DMEM medium (Gibco; Thermo Fisher Scientific, Inc.), supplemented with 10\% FBS (Gibco; Thermo Fisher Scientific, Inc.) in a humidified atmosphere of $5 \% \mathrm{CO}_{2}$ at $37^{\circ} \mathrm{C}$. Images of the cells were captured using the EVOS FL microscope $\left(\right.$ EVOS $^{\circledast}$ FL; Thermo Fisher Scientific, Inc.). Small interfering RNAs (siRNAs) were used to knockdown the endogenous gene expression of $R O N$ or snail family transcriptional repressor 2 (SLUG) in OSCC cells. OSCC cells were seeded in 6-well plates at a density of $2 \times 10^{5}$ cells/well and transfected with a $100 \mathrm{pmol} R O N$-specific (cat. no. sc-36434; Santa Cruz Biotechnology, Inc), 100 pmol $S L U G$-specific (cat. no. 6591; Bioneer Corporation) or 100 pmol negative control siRNA (cat. no. 1027281; Qiagen, Inc.), using Lipofectamine RNAiMAX (Invitrogen; Thermo Fisher Scientific, Inc.) for $48 \mathrm{~h}$ at $37^{\circ} \mathrm{C}$, and then after $24-48 \mathrm{~h}$, the subsequent experiments were performed.

Protein isolation and western blotting analysis. Cells were lysed in RIPA assay buffer (Biosesang, Inc.) and protein concentrations were determined using a bicinchoninic acid assay. Protein lysates (20-30 $\mu \mathrm{g}$ ) were separated by SDS-PAGE (10-12\% gels) and then electrophoretically transferred onto PVDF membranes. Membranes were incubated for $1 \mathrm{~h}$ with 5\% BSA (Bioshop Canada, Inc.) in 0.1\% TBS-Tween-20 at room temperature and then washed four times, for $15 \mathrm{~min}$ each, with $0.1 \%$ TBS-Tween-20. Specific proteins were sequentially detected with primary antibodies against RON (cat. no. sc-25781) and GAPDH (cat. no. sc-25778) from Santa Cruz Biotechnology, Inc., and cleaved caspase-3 (cat. no. 9664), cleaved caspase-7 (cat. no. 9491), cleaved caspase-9 (cat. no. 9501), cleaved poly(ADP-ribose)polymerase (PARP; cat. no. 5625), SLUG (cat. no. 9585), phospho-ERK1/2 (cat. no. 4370), phospho-c-JNK (cat. no. 4511), phospho-p38 (cat. no. 4511), total ERK (cat. no. 4695), total JNK (cat. no. 9258) and total p-38 (cat. no. 9212) obtained from Cell Signaling Technology, Inc. Primary antibodies were diluted 1:1,000 and incubated with membranes for $24 \mathrm{~h}$ at $4^{\circ} \mathrm{C}$. Anti-rabbit (cat. no. 7074; Cell Signaling Technology, Inc.) or anti-mouse (cat. no. 7076; Cell Signaling Technology, Inc.) horseradish peroxidase (HRP)-conjugated secondary antibodies were diluted 1:2,000 and incubated with membranes at room temperature for $2 \mathrm{~h}$. Immunoreactive proteins were visualized using an enhanced chemiluminescence detection system for HRP (EMD Millipore), and images were showed using an LAS-4000 luminescent image analyzer (Image Leader LAS 4000IR, Fujifilm). Band densitometry was analyzed using an Multi gauge V3.2 (Fujifilm).

$R N A$ isolation, reverse transcription polymerase chain reaction (RT-PCR) and RT-quantitative PCR (RT-qPCR). Total RNA was extracted from cells using TRIzol reagent (Invitrogen; Thermo Fisher Scientific, Inc.), according to the manufacturer's protocol. RT was performed using $1 \mu \mathrm{g}$ of total RNA, M-MLV reverse transcriptase (Invitrogen; Thermo Fisher Scientific, Inc.), $1 \mu 110 \mathrm{mM}$ dNTP mix (Enzynomics Co., Ltd.), $1 \mu \mathrm{l}$ oligo dT (500 $\mu \mathrm{g} / \mathrm{ml}$; Promega Corporation), $2 \mu \mathrm{l} 0.1 \mathrm{M}$ dithiothreitol (Invitrogen; Thermo Fisher Scientific, Inc.), $4 \mu 15 \mathrm{X}$ first-strand buffer (Invitrogen; Thermo Fisher Scientific, Inc.) and $1 \mu 1$ RNase inhibitor (Promega Corporation). For the first step, dNTP and oligo dT were added at $65^{\circ} \mathrm{C}$ for $10 \mathrm{~min}$, and the second step was performed using RNA, dithiothreitol, 5X first-strand buffer, RNase inhibitor, M-MLV reverse transcriptase at $37^{\circ} \mathrm{C}$ for $60 \mathrm{~min}$, and then $70^{\circ} \mathrm{C}$ for $10 \mathrm{~min}$, according to the manufacturer's protocol. cDNA was then amplified using primers specific for $R O N$, $S L U G$ and GAPDH (Bioneer Corporation), as previously described (22). PCR was performed using GoTaq DNA Polymerase and 5X Green GoTaq reaction buffer (Promega Corporation). The primer sequences were as follows: RON forward, 5'-TCGCCTCGATGGAGCTCCTC-3'; RON reverse, 5'-CATGTGTGCCACTGTGACGT-3'; SLUG forward, 5'-CGAACTGGACACACATACAGTG-3'; SLUG reverse, 5'-CTGAGGATCTCTGGTTGTGGT-3'; GAPDH forward, 5'-ACCACAGTCCATGCCATCAC-3'; and GAPDH reverse, 5'-TCCACCCTGTTGCTGTA-3'. PCR products were separated by electrophoresis on a $1 \%$ agarose gel containing ethidium bromide.

qPCR analysis was performed using the QuantiSpeed SYBR Green kit (cat. no. 105-02; Philekorea, Korea) with the Rotor-Gene 6000 real-time rotary analyzer (Corbett Life Science), and confirmed using melting curve analysis. Amplification plots were used to evaluate the quantification cycle $(\mathrm{Cq})$. The sequences of the qPCR primers used were as follows:RONforward,5'-CTTTGACGTGAAGTACGTGGT-3'; RON reverse, 5'-CGTATGGCTACAAACACAGCAC-3'; 
SLUG forward, 5'-CGAACTGGACACACATACAGTG-3'; SLUG reverse, 5'-CTGAGGATCTCTGGTTGTGGT-3'; 18S rRNA forward, 5'-GTAACCCGTTGAACCCCATT-3'; 18S rRNA reverse 5'-CCATCCAATCGGTAGTAGCG-3. qPCR was performed at $95^{\circ} \mathrm{C}$ for $2 \mathrm{~min}$ for 1 cycle, and then $95^{\circ} \mathrm{C}$ for $5 \mathrm{sec}, 60^{\circ} \mathrm{C}$ for $20 \mathrm{sec}$ for 40 cycles.

Cell invasion assay. Cell invasion ability was determined by the number of cells that invaded through a Transwell invasion apparatus with 8.0- $\mu \mathrm{m}$ pores (Costar; Corning, Inc.). At $48 \mathrm{~h}$ after transfection, cells transfected with $R O N$ or $S L U G$ siRNA or a negative control siRNA were seeded at $3 \times 10^{5}$ cells in $120 \mu \mathrm{l}$ medium containing $0.2 \%$ BSA (BioShop, Inc.) suspension in the upper chamber. The lower chamber was filled with $400 \mu \mathrm{l}$ medium containing $0.2 \%$ BSA containing $100 \mathrm{ng} / \mathrm{ml}$ MSP (cat. no. 352-MS; R\&D Systems, Inc.) into the lower chamber as the chemoattractant. After incubation for $24 \mathrm{~h}$, cells that had moved to the bottom Transwell surface were stained with Diff-Quik solution (Sysmex Corporation) and were counted in five random squares in the microscopic field of view. Results are presented as the mean $\pm \mathrm{SE}$ of the number of cells/field from three individual experiments.

Cell migration assay (wound healing assay). At $24 \mathrm{~h}$ after transfection, cells transfected with a RON-specific, SLUG-specific or negative control siRNA were seeded in each well of Culture-Inserts (Ibidi $\mathrm{GmbH}$ ) at $1.5 \times 10^{5}$ cells/well. After incubation for $24 \mathrm{~h}$, each insert was detached and the progression of cell migration was ascertained by imaging at $0,8,12$ and $24 \mathrm{~h}$, using an inverted microscope. Distances between gaps were normalized to $1 \mathrm{~cm}$ after capture of three random sites.

Apoptosis assay. Apoptosis was determined using an Annexin V-FITC assay (cat. no. 556547; BD Biosciences). At $48 \mathrm{~h}$ after transfection, cells transfected with a $R O N$-specific siRNA or a negative control siRNA were collected using trypsin, washed twice in PBS, and re-suspended in binding buffer (BD Biosciences). Annexin V-FITC and 7-amino-actinomycin D (BD Biosciences) were added to the cells, which were incubated in the dark for $15 \mathrm{~min}$ and then re-suspended in $400 \mathrm{ml}$ binding buffer. Cells were analyzed using a FACSCalibur flow cytometer (BD Biosciences; Becton, Dickinson and Company) and BD CellQuest version 3.3 software (Becton, Dickinson and Company). Data analysis was performed using WinMDI version 2.9 (The Scripps Research Institute).

Patients and tumor specimens. To evaluate RON protein expression, paraffin-embedded tissue sections were collected from 99 patients who had undergone a diagnostic biopsy or definitive surgery for OSCC at Chonnam National University Hwasun Hospital (Jeonnam, Korea) between May 2004 and August 2013. None of the collected tissues were obtained after radiotherapy or chemotherapy. Of these, 10 patients were excluded because of follow-up loss or palliative treatment intent. A total of 67 men and 22 women participated in the present study with a mean age of $62.7 \pm 12.8$ years (range, $26-87$ years). Of the 89 patients, 86 were treated with definitive surgery, with or without adjuvant radiotherapy, or with cisplatin-based concurrent chemoradiotherapy (CRT). Three patients that refused surgery were treated with induction chemotherapy, followed by cisplatin-based concurrent CRT, with curative intent. The incidence of recurrence included locoregional recurrence and/or distant metastasis after primary treatment with curative intent. Patients with locoregional recurrence underwent salvage surgery or CRT. Treatment failure was defined as disease with inoperable locoregional progression or distant metastasis, even with salvage treatment. Patients' clinicopathologic characteristics and complete medical history, were reviewed in hospital records. Tumors were staged according to the 7th edition of the American Joint Committee on Cancer staging system (23). Survival duration (months) was measured from the date of starting treatment to the date of death or the date last seen. Disease-free survival (DFS) was measured to the first observed date of any recurrence or death and disease-specific survival (DSS) to the date of OSCC-related death.

To evaluate RON mRNA expression, fresh OSCC tissues and paired normal oral mucosa were collected from 20 patients that underwent diagnostic biopsy or definitive surgery of OSCC at CNUHH. A total of 12 men and 8 women participated in the present study with a mean age of $66.2 \pm 15.4$ years (range, 23-86 years). RON mRNA expression was analyzed by RT-PCR and RT-qPCR, performed as described above. Due to the small amount of fresh tissue obtained during diagnostic biopsy, western blotting could not be performed to measure RON protein expression.

Patient dataset from The Cancer Genome Atlas (TCGA). The TCGA (portal.gdc.cancer.gov/) head and neck cancer dataset included 530 samples across all anatomical sites of the head and neck. For this study, only OSCC patients with DFS status information were selected, eliminated duplicate samples of the same patient in the dataset, and finally included 226 patients in this analysis. RNA-seq data was analyzed as expected maximization (RSEM) values of MST1R expression, which were $\log 2$ transformed (RSEM+1). The mean of MST1R expression levels was used as a cutoff value for classification into low or high RON expression groups in survival analyses.

Immunohistochemistry. Tissue processing and immunohistochemical analysis were performed as previously described (22). Tissue sections were incubated with primary antibodies against RON (cat. no. sc-25781; Santa Cruz Biotechnology). Two independent observers interpreted RON staining with no knowledge of the associated clinical information. Staining intensity was scored as follows: 0 , no staining of tumor cells; 1+, weak-to-comparable staining in the cytoplasm and/or nucleus, compared to non-tumor cell staining; $2+$, readily appreciable or dark brown staining distinctly marking the tumor cell cytoplasm and/or nucleus. Percentages of stained cells were scored as follows: $0,0 \% ; 1,1-25 \% ; 2,26-50 \% ; 3,51-75 \%$; and $4,>75 \%$. Final staining scores were the product of the intensity and percentage scores, with $\leq 4$ defined as low RON expression and $>4$ defined as high RON expression.

Statistical analysis. The significance of experimental differences was assessed using Student's t-test. Association between RON expression and various clinicopathological parameters were compared using the $\chi^{2}$ test or Fisher's exact 

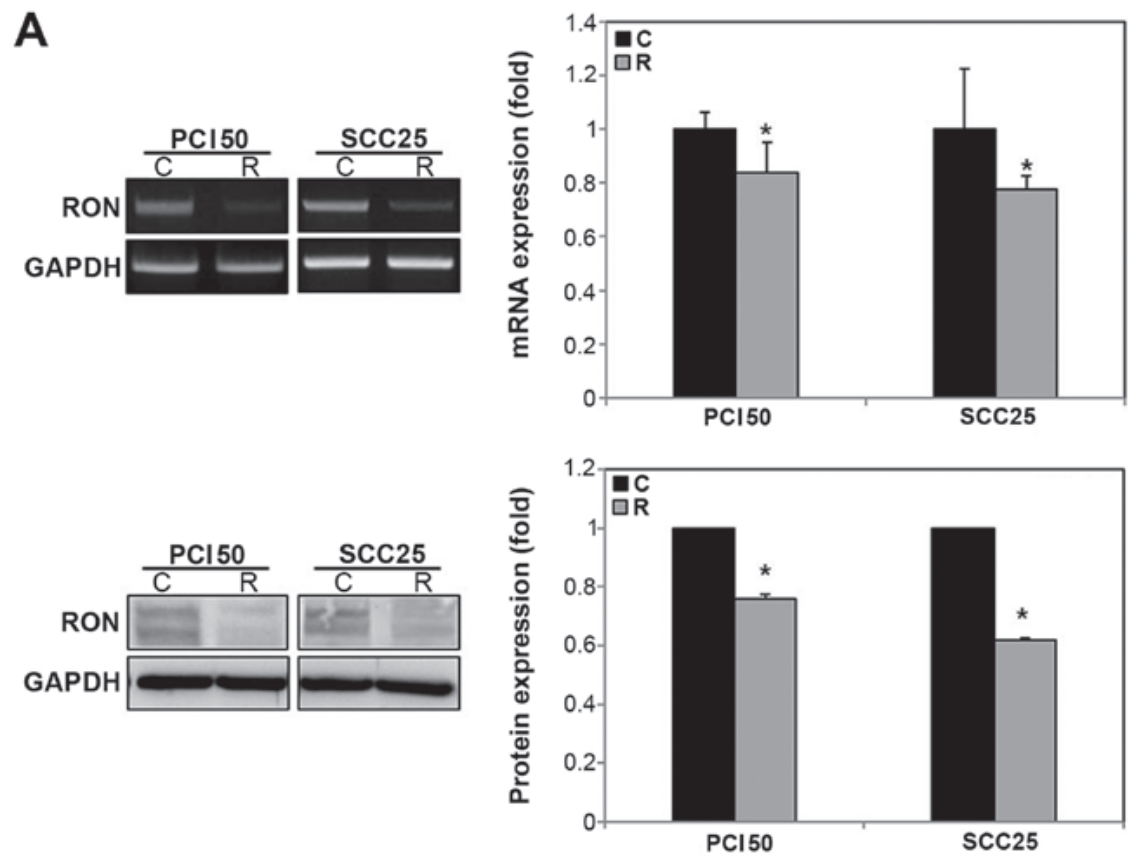

B
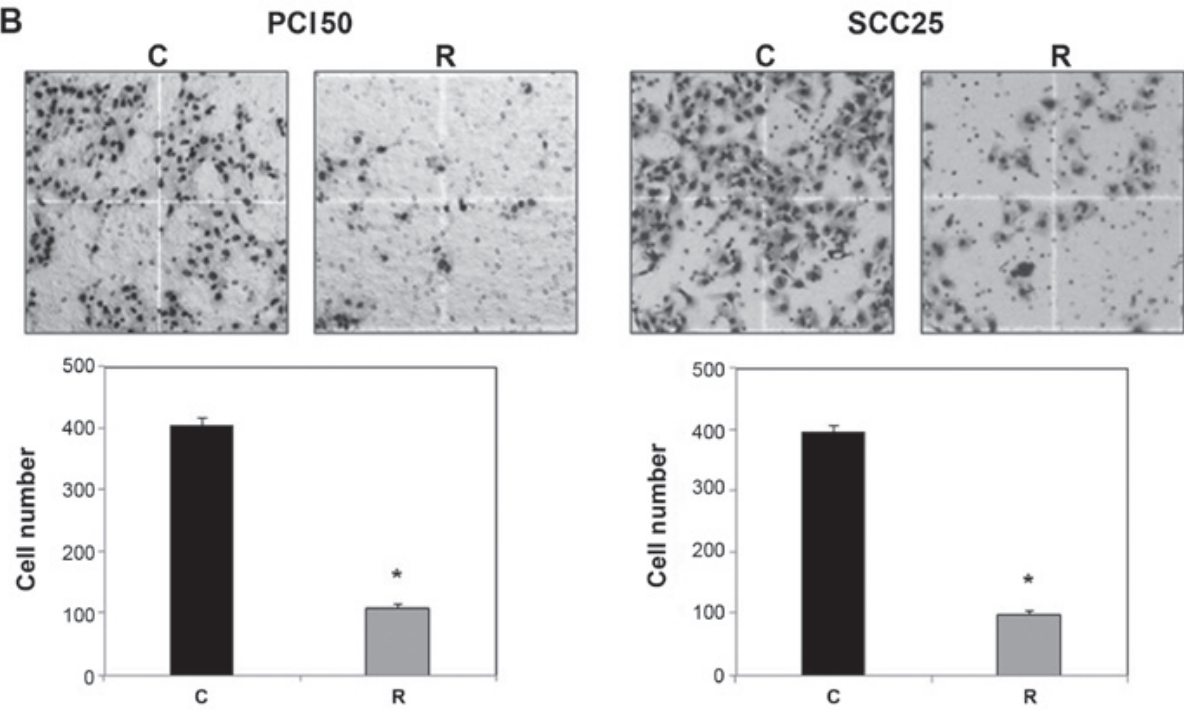

Figure 1. Effect of RON knockdown on cell invasion in human oral squamous cell carcinoma cells. (A) RON mRNA and protein were reduced by RON siRNA in PCI50 and SCC25 cells compared with negative control siRNA, as shown by RT-PCR (upper left panel) and RT-quantitative PCR (upper right panel), as well as by western blotting (lower panels). (B) In a cell invasion assay, significantly fewer RON knockdown PCI50 and SCC25 cells invaded than did negative control cells. Stained invading cells were counted (bar graph; mean \pm SE of three independent experiments; ${ }^{*} \mathrm{P}<0.05$ vs. C). RT, reverse transcription; RON, recepteur d'origine nantais; siRNA, small interfering RNA; C, negative control siRNA transfected cells; R, RON-specific siRNA transfected cells.

test. Survival curves were calculated by the Kaplan-Meier method and were compared using the log-rank test. Analyses were performed using SPSS version 21.0 (IBM, Corp.). $\mathrm{P}<0.05$ was considered to indicate a statistically significant difference.

\section{Results}

Knockdown of RON suppresses tumor cell invasion in human OSCC cells. To examine the role of RON in tumor progression, the present study used siRNA to inhibit the endogenous expression of RON in the human OSCC cells, PCI50 and SCC25. The mRNA and protein levels of RON were lower in the $R O N$-specific siRNA-treated PCI50 and SCC25 cells than in the negative control siRNA-treated cells (Fig. 1A).
The number of invading $R O N$-knockdown PCI50 cells was $109.0 \pm 6.4$, compared with $406.3 \pm 11.7$ invading negative control PCI50 cells (Fig. 1B). The number of invading RON-knockdown SCC25 cells was 99.5 \pm 5.3 , compared with $396.5 \pm 27.1$ invading negative control SCC25 cells (Fig. 1B). The difference between the two groups was statistically significant $(\mathrm{P}<0.05)$.

Knockdown of RON suppresses tumor cell migration and RON activation by MSP enhances cell migration in human OSCC cells. With time, the artificial wound gap became significantly narrower in plates of negative control PCI50 and SCC25 cells at 8,12 and $24 \mathrm{~h}$, compared with RON-knockdown cells $(\mathrm{P}<0.05$; Fig. 2A and C). Wound gaps were not filled, even after $24 \mathrm{~h}$, in plates of negative control PCI50 and SCC25 cells. Therefore, 
A

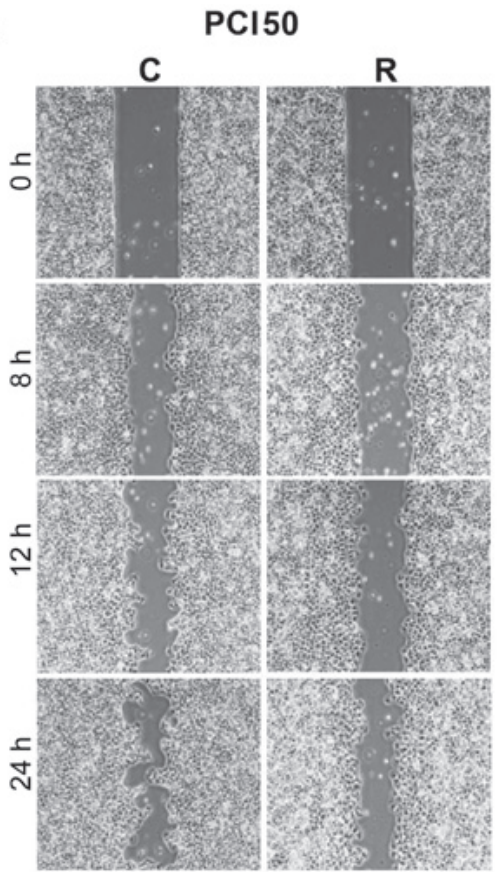

$\operatorname{SCC} 25$

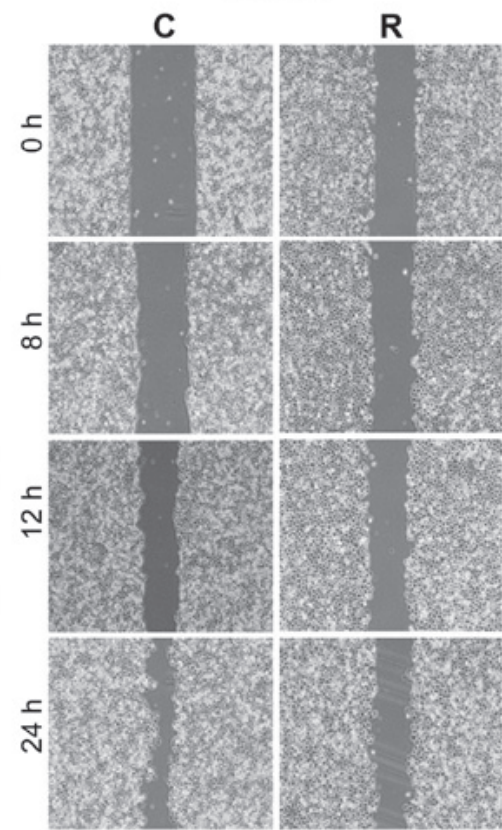

B

MSP $100 \mathrm{ng} / \mathrm{ml}$
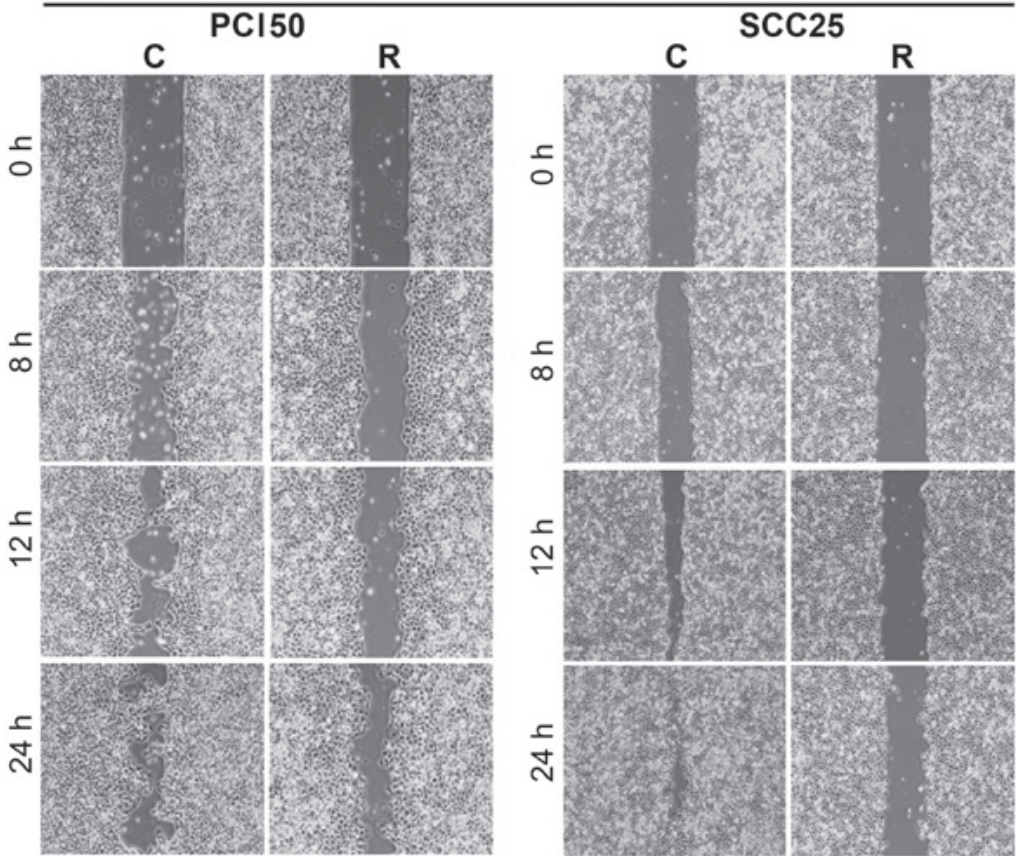

C

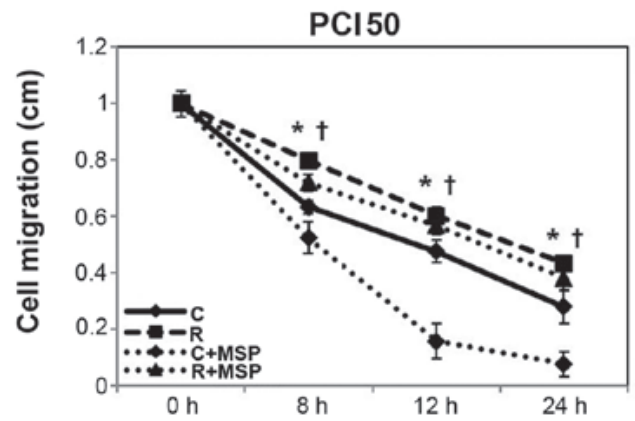

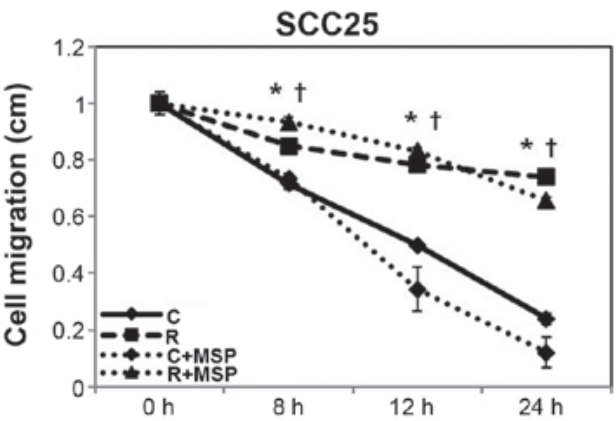

Figure 2. Effect of RON knockdown on cell migration with or without RON ligand, MSP in human oral squamous cell carcinoma cells. (A) Cell migration without MSP, was significantly less in RON knockdown PCI50 and SCC25 cells than in negative control cells. (B) Cell migration increased by RON activation by MSP in negative control PCI50 and SCC25 cells. The artificial wound gap in negative control cells with MSP became significantly narrower than in RON knockdown PCI50 and SCC25 cells. (C) Cell migration is displayed as relative healing distances measured in three random sites. Values indicate mean \pm SE for three independent experiments ( $\mathrm{P}<0.05$, R vs. C; ${ }^{\dagger} \mathrm{P}<0.05, \mathrm{R}+\mathrm{MSP}$ vs. C + MSP). RON, recepteur d'origine nantais; siRNA, small interfering RNA; $\mathrm{C}$, negative control siRNA transfected cells; R, RON-specific siRNA transfected cells; MSP, macrophage-stimulation protein. 
A
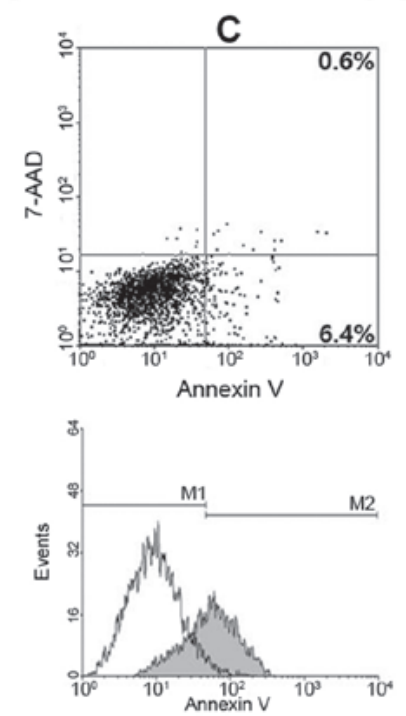

$\mathrm{PCI50}$
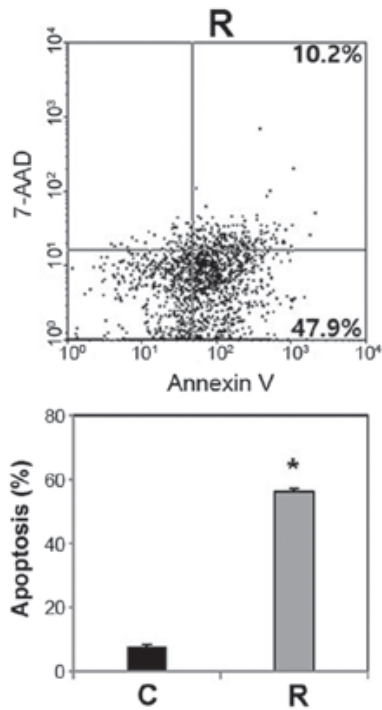

$\operatorname{scc} 25$
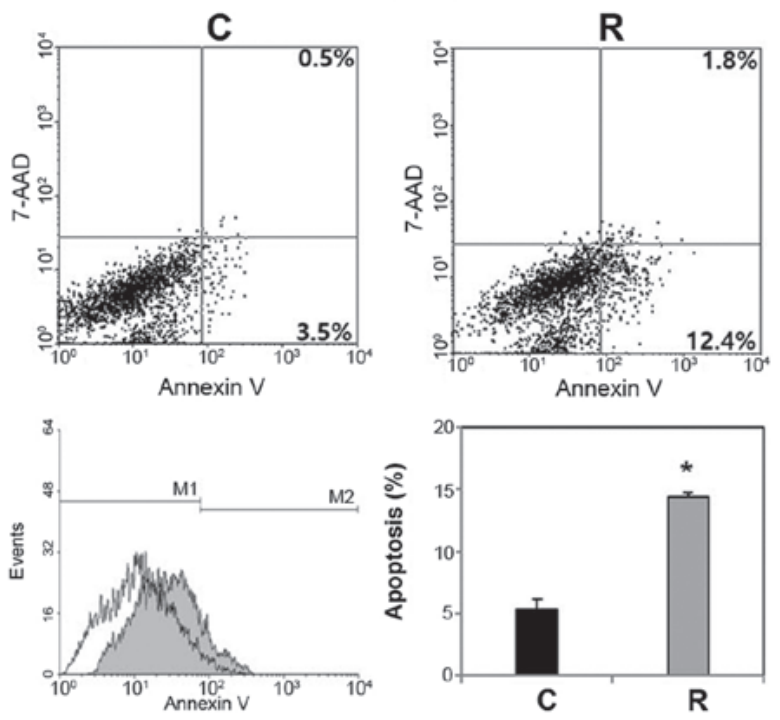

B

Cleaved caspase-3

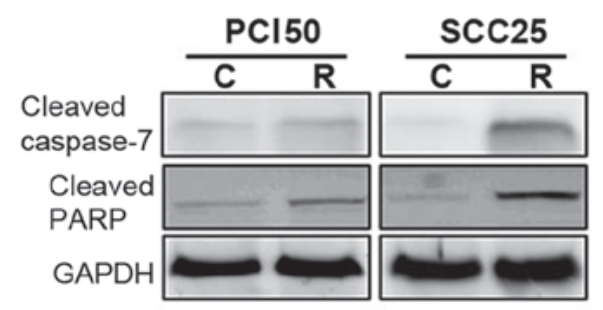

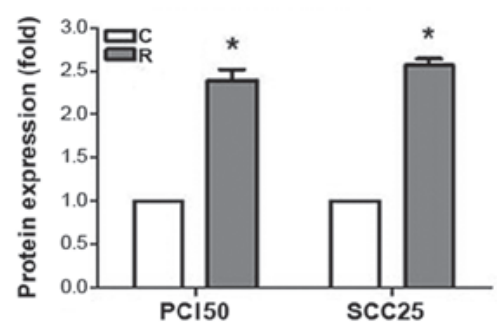

Cleaved caspase-7

$\operatorname{scC25}$
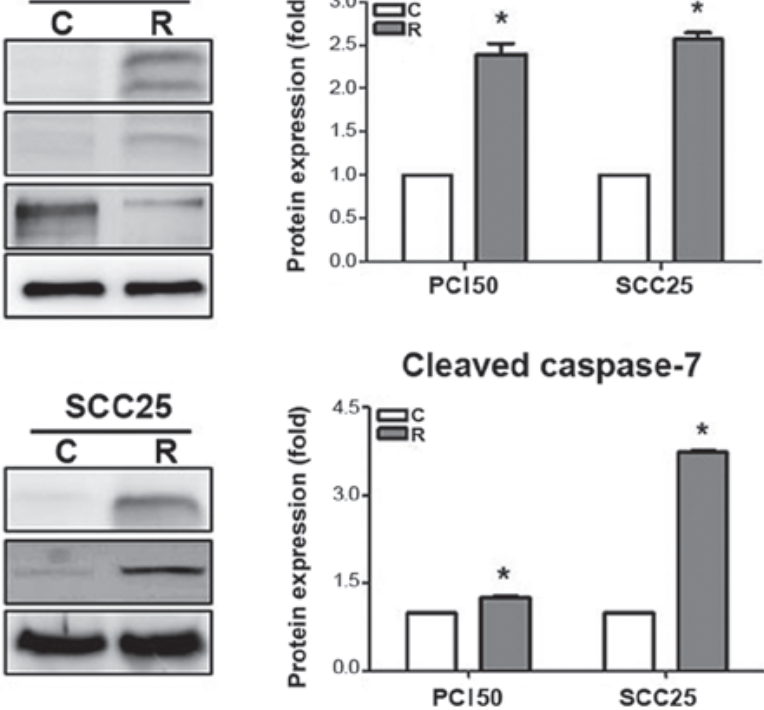

Cleaved caspase-9

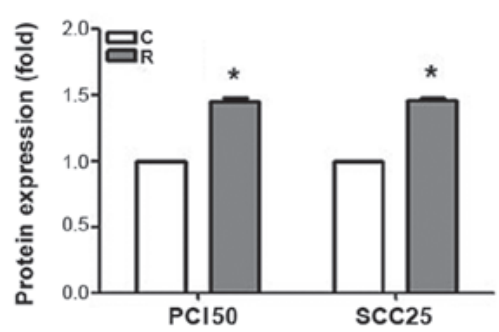

Cleaved PARP

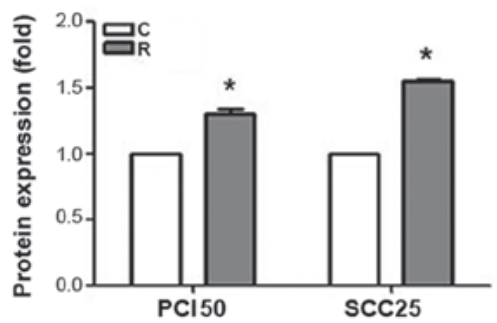

Figure 3. Effect of RON knockdown on cell apoptosis in human oral squamous cell carcinoma cells. (A) Representative dot plots and histogram showed that RON knockdown PCI50 and SCC25 cells displayed more apoptosis than in control cells. (B) Levels of cleaved caspases-3, -7, and -9, and cleaved PARP were greater in RON knockdown PCI50 and SCC25 cells than in control cells ( $\mathrm{P}<0.05$ vs. C). siRNA, small interfering RNA; 7-AAD, 7-amino-actinomycin D; C, negative control siRNA transfected cells; R, RON-specific siRNA transfected cells; M1, normal cells; M2, apoptotic cells; RON, recepteur d'origine nantais; PARP, poly(ADP-ribose)polymerase.

in order to achieve greater activation of RON signaling, $100 \mathrm{ng} / \mathrm{ml}$ of the RON ligand, MSP, was applied to the plates of PCI50 and SCC25 cells. Migration of PCI50 and SCC25 cells increased after incubation with MSP and the artificial wound gap in plates of negative control cells became significantly narrower than the wound gap in RON-knockdown cells at 8 , 12, and $24 \mathrm{~h}(\mathrm{P}<0.05$; Fig. $2 \mathrm{~B}$ and $\mathrm{C})$. This result demonstrated that ligand-mediated activation of RON enhanced cell migration.

Knockdown of RON enhances tumor cell apoptosis in human OSCC cells. To investigate the effect of RON on apoptosis, we used an Annexin V apoptosis assay. Flow cytometric analysis indicated that $R O N$ knockdown significantly increased the proportion of apoptotic cells (Fig. 3A). The proportion of early and late apoptotic cells induced by transfection of $R O N$-specific siRNA were greater than in the cells transfected with negative control siRNA (58.1 vs. $7.0 \%$ and 14.2 vs. $4.0 \%$, respectively) in PCI50 and SCC25 cells. To confirm this effect of RON knockdown on tumor cell apoptosis, apoptosis regulatory proteins were evaluated after siRNA treatment. Levels of cleaved caspase-3, -7 and -9 and PARP were higher in $R O N$-knockdown PCI50 and SCC25 cells, compared with negative control cells (Fig. 3B). These results indicate that $R O N$ knockdown induces tumor cell apoptosis by modulating apoptosis regulatory proteins, such as caspases-3, -7 and -9 and PARP in human OSCC cells.

Knockdown of RON decreases the expression of epithelial-mesenchymal transition (EMT)-related transcription 
A

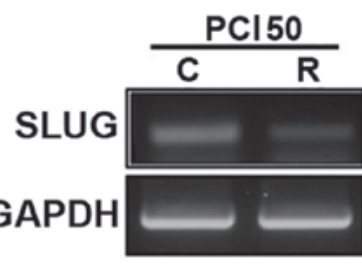

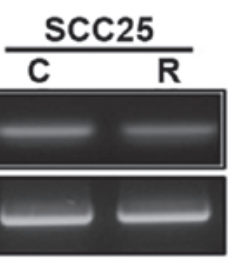

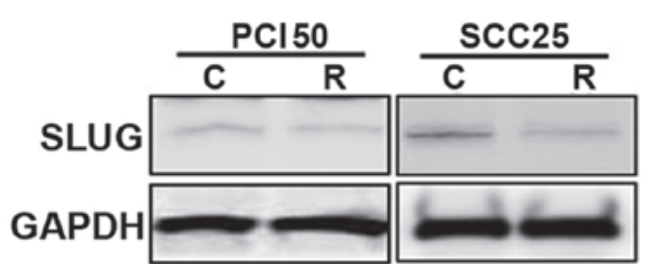

B

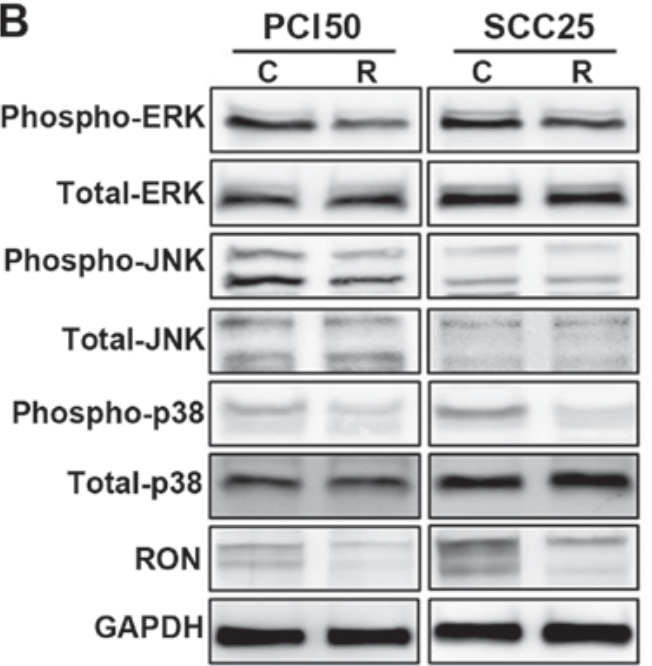

Phospho/Total JNK
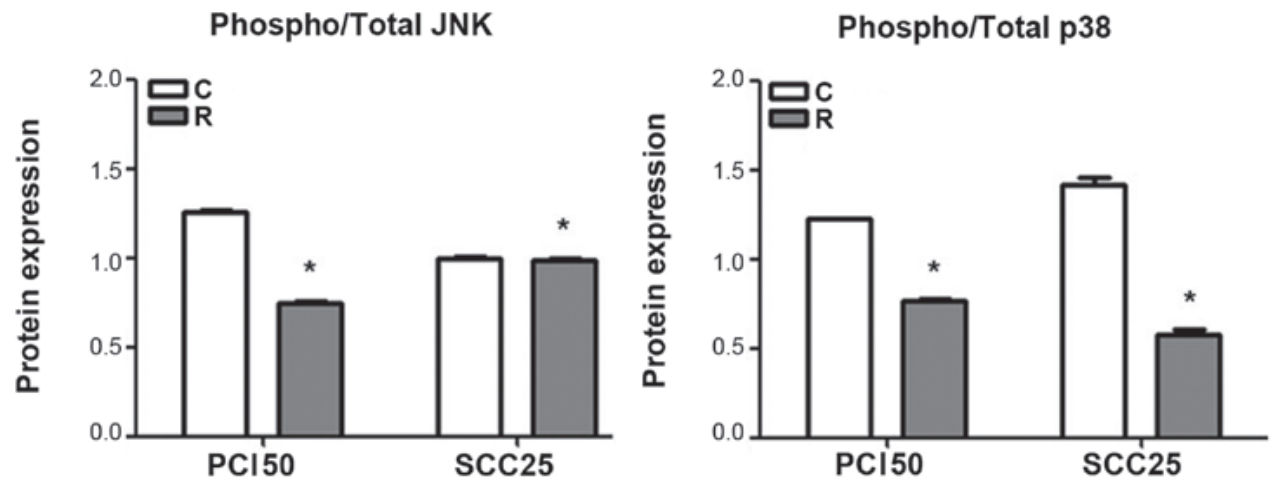

Figure 4. Effect of RON knockdown on epithelial-mesenchymal transition -related transcription factor, SLUG and mitogen-activated protein kinase pathways in human oral squamous cell carcinoma cells. (A) RON knockdown reduced the expression of SLUG mRNA and protein in PCI50 and SCC25 cells. (B) The phosphorylation levels of ERK1/2, JNK and p38 were decreased by RON knockdown in PCI50 and SCC25 cells ("P<0.05 vs. C). RON, recepteur d'origine nantais; siRNA, small interfering RNA; C, negative control siRNA transfected cells; R, RON-specific siRNA transfected cells; SLUG, snail family transcriptional repressor 2 .

factor, SLUG, and the phosphorylation of MAPK signaling proteins in human OSCC cells. To examine the potential mechanisms involved in the effects of $R O N$ knockdown on aggressive tumor cell behavior, we investigated the impact of $R O N$ knockdown on the EMT-related protein, SLUG and the MAPK signaling proteins. SLUG is known to be involved in cell invasion and metastasis, and the MAPK signaling pathways are essential for cell growth and survival. RON knockdown reduced the expression of SLUG mRNA and protein in PCI50 and SCC25 cells (Fig. 4A). In addition, the phosphorylation levels of ERK1/2 and p38 were decreased significantly by RON knockdown in PCI50 and SCC25 cells. RON knockdown also decreased the levels of phospho-JNK in PCI50 cells, but not in SCC25 cells (Fig. 4B).

Knockdown of SLUG eliminates the effect of RON activation by MSP to aggressive cell behavior in human OSCC cells.
The mRNA and protein levels of SLUG were lower in $S L U G$-specific siRNA-transfected PCI50 and SCC25 cells compared with those in the negative control siRNA-transfected cells (Fig. 5A).

To verify the relationship between RON and SLUG, cell invasion and migration were compared in negative control OSCC cells and $S L U G$-knockdown OSCC cells after RON activation by treatment with $200 \mathrm{ng} / \mathrm{ml} \mathrm{MSP}$. The number of invading $S L U G$-knockdown PCI50 cells was $1.2 \pm 0.7$, compared with $153.3 \pm 14.1$ invading negative control PCI50 cells (Fig. 5B). The number of invading SLUG-knockdown SCC25 cells was $5.5 \pm 1.4$, compared with $170.1 \pm 14.3$ invading negative control SCC25 cells (Fig. 5B). The difference between the two groups was statistically significant $(\mathrm{P}<0.05)$. With time, the artificial wound gap became significantly narrower in plates of negative control PCI50 and SCC25 cells at 4,8 and 12 h, compared with $S L U G$-knockdown cells after 
A
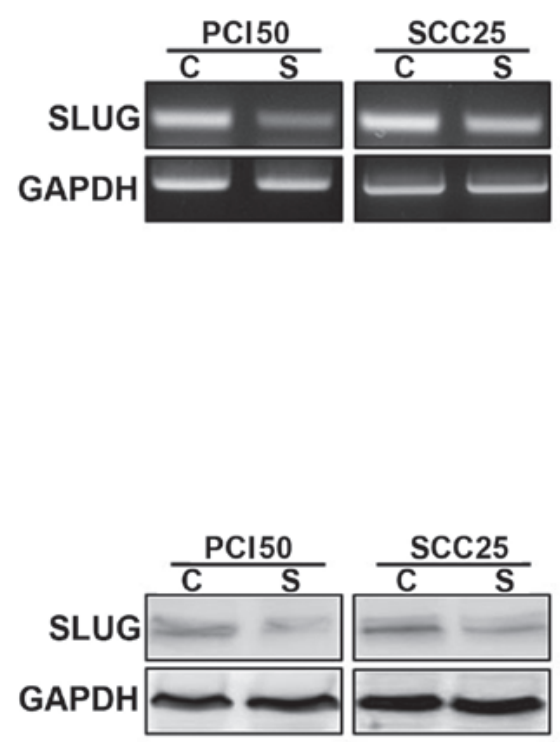

B
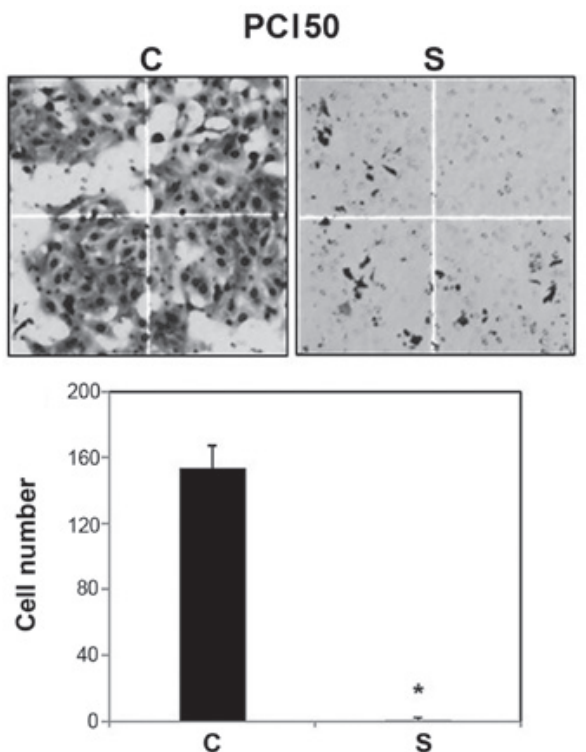
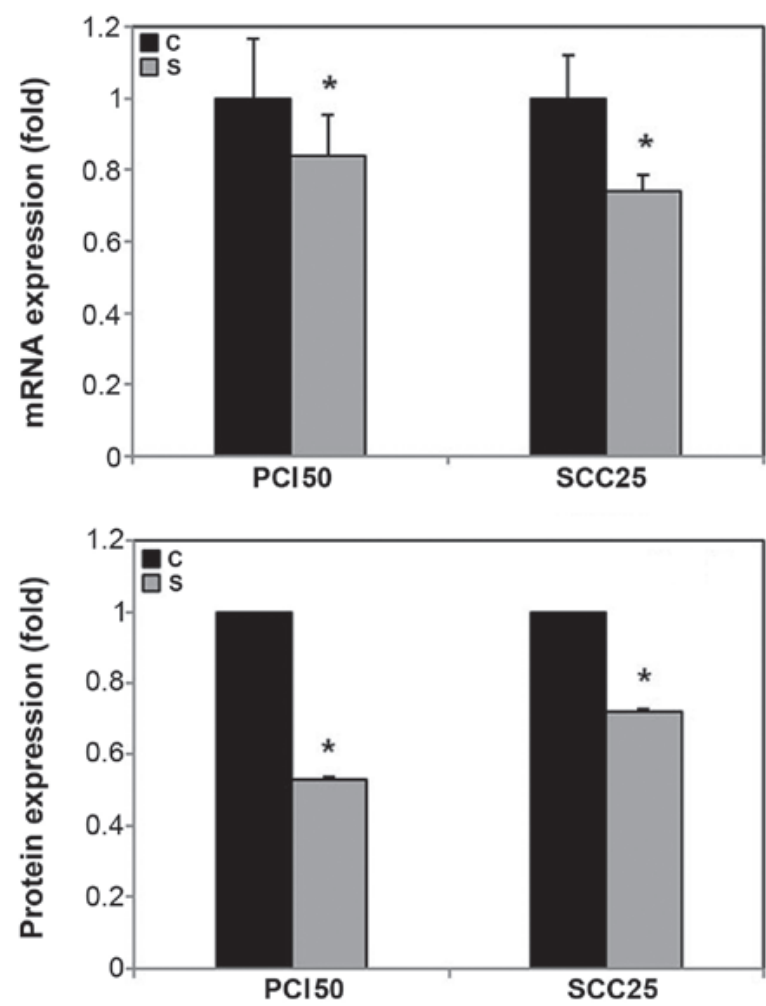
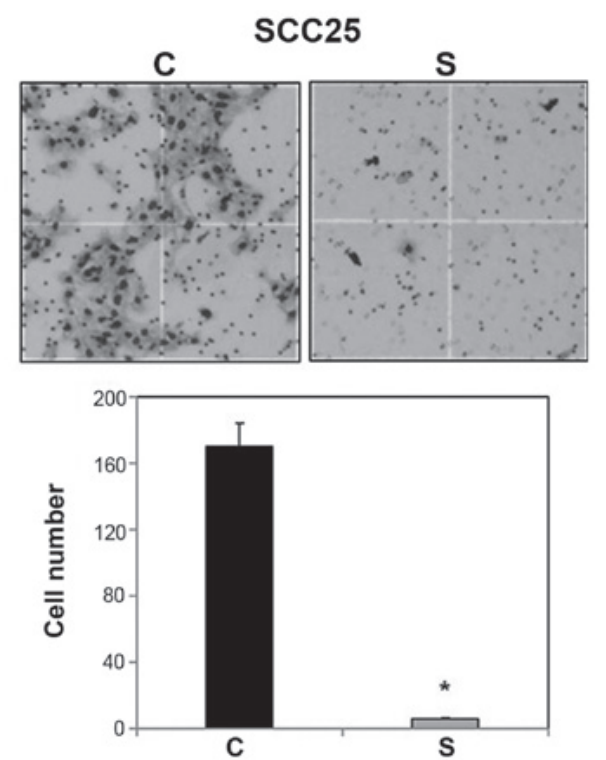

Figure 5. Effect of SLUG knockdown on cell invasion and migration under RON activation by MSP in human oral squamous cell carcinoma cells. (A) SLUG mRNA and protein were reduced by SLUG siRNA in PCI50 and SCC25 cells compared with negative control siRNA as shown by RT-PCR (upper left panel) and RT-qPCR (upper right panel), as well as by western blotting (lower panel). (B) In cell invasion assay, significantly fewer SLUG knockdown PCI50 and SCC25 cells invaded than did negative control cells. Stained invading cells were counted (bar graph; mean \pm SE, experiments were run in triplicate; ${ }^{*} \mathrm{P}<0.05$ ).

MSP-induced RON activation $(\mathrm{P}<0.05$; Fig. 5C). This result demonstrated that $S L U G$ knockdown blocks the enhancement of cell migration induced by RON activation in OSCC cells.

RON activation by its ligand, MSP, induces morphological changes in human OSCC cells. To demonstrate the role of RON in EMT, morphological changes in PCI50 and SCC25 cells treated with $500 \mathrm{ng} / \mathrm{ml}$ MSP for 48 and $72 \mathrm{~h}$ were analyzed. Light microscopy showed a scattering effect, indicating cell-cell dissociation (Fig. 6). The individual cell morphology also was changed to an elongated and spindle-like shape.
These findings suggested that MSP-induced RON activation is involved in the process of EMT at the cellular level.

Expression of RON is high in human OSCC tissues. The patients in this study included 67 men and 22 women. The mean age was $62.7 \pm 12.8$ years (mean $\pm \mathrm{SD}$ ), with a range of $26-87$ years. The mean patient follow-up period was $59.5 \pm 38.1$ months, with a range of 3.6-156.3 months. RON protein expression was investigated by immunohistochemical staining of formalin-fixed, paraffin-embedded biopsy tissue obtained from 89 patients with OSCC. Immunostaining patterns were 


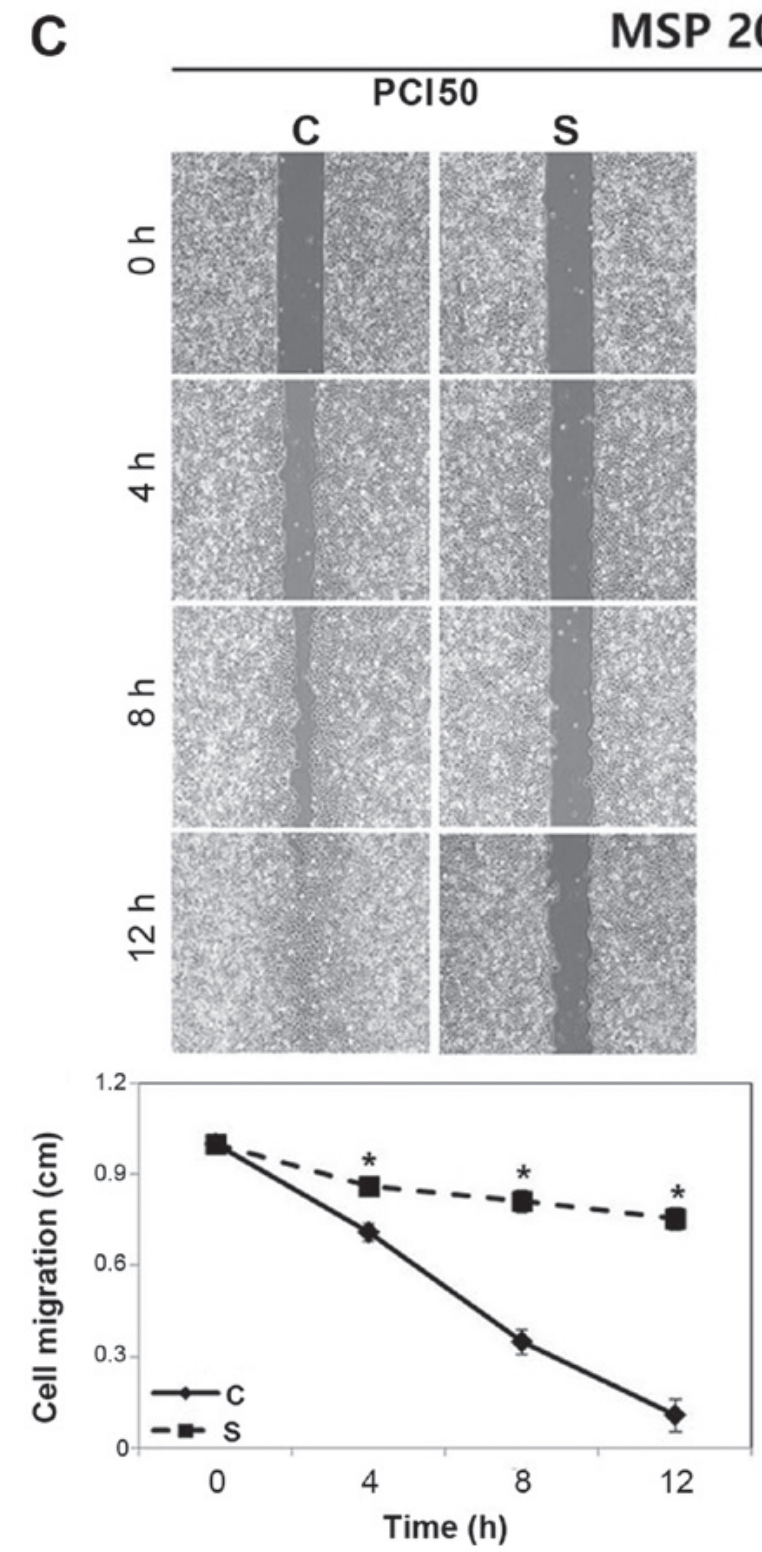

MSP $200 \mathrm{ng} / \mathrm{ml}$
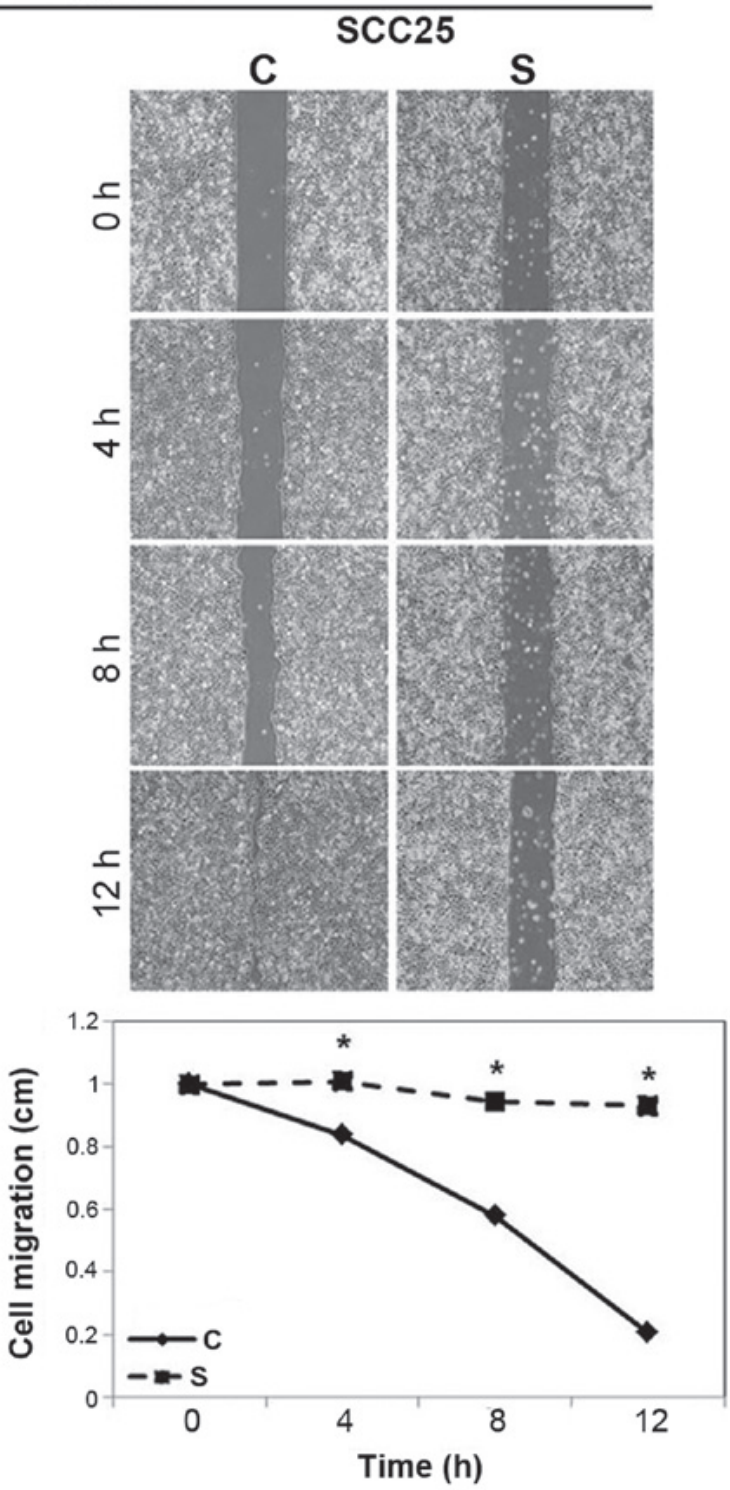

Figure 5. Continued. (C) Cell migration with MSP, was significantly less in SLUG knockdown PCI50 and SCC25 cells than in negative control cells. Cell migration is displayed as relative healing distances measured in three random sites. Values indicate mean $\pm \mathrm{SE}$ for three independent experiments $($ ( $\mathrm{P}<0.05)$. RON, recepteur d'origine nantais; siRNA, small interfering RNA; C, negative control siRNA transfected cells; S, SLUG-specific siRNA transfected cells; SLUG, snail family transcriptional repressor 2; MSP, macrophage-stimulation protein.

heterogenous, with predominantly nuclear and/or cytoplasmic staining in tumor cells, but weak or no staining in the normal adjacent tissues (Fig. 7). Based on the grading criteria, high RON expression was observed in $43.8 \%$ of patients (39/89) and low RON expression was observed in $56.2 \%$ of patients (50/89).

Patient data and the correlation between RON expression and various OSCC clinicopathological variables are shown in Table I. RON expression in OSCC was not associated with age, sex, tumor location, tumor stage, $\mathrm{T}$ stage, $\mathrm{N}$ stage or chemoradiotherapy treatment $(\mathrm{P}>0.05)$. Patients with high RON expression tended to have a second primary malignancy more often than those with low RON expression $[24.0 \%(12 / 50)$ in the low-expression group vs. $41.0 \%$ (16/39) in the high-expression group]. This may be weak evidence that RON is involved in the carcinogenesis of human cancers. Patients with high RON expression had marginally higher rates of recurrence and treatment failure rate than those with low RON expression, but this was not a significant difference ( $P>0.05$; Table II).

For the 89 patients with OSCC enrolled in this study, the $3 / 5$-year DSS was $68 / 67 \%$ and the $3 / 5$-year DFS was $64 / 58 \%$. The 3-year DSS/DFS rates in patients with high RON expression were lower than those with low RON expression ( $72 / 70 \%$ in the low-expression group vs. 64/56\% in the high-expression group); however, analysis of Kaplan-Meier curves for DSS/DFS using the log-rank test, did not demonstrate a significant difference between these two groups of patients ( $P>0.05$; Fig. 8). For the 226 patients with OSCC in the TCGA dataset, the 3-year DFS rates in patients with high RON expression were lower than in those with low RON expression (60\% in the low-expression group vs. $51 \%$ in the high-expression group). Similar to the previous results of patients from Chonnam National University Hwasun Hospital, the TCGA data showed no statistically 


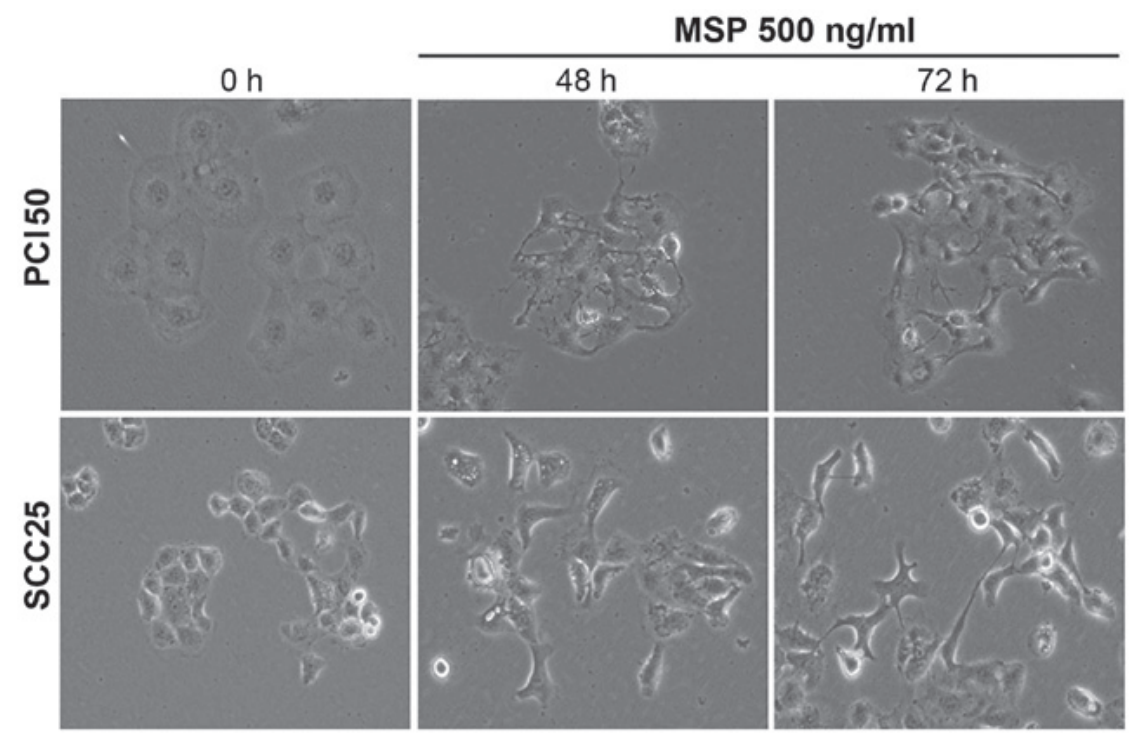

Figure 6. Morphological changes under RON activation by MSP in human oral squamous cell carcinoma cells. The cell morphology in PCI50 and SCC25 cells with $500 \mathrm{ng} / \mathrm{ml} \mathrm{MSP,} \mathrm{was} \mathrm{changed} \mathrm{to} \mathrm{spindle-like} \mathrm{shape} \mathrm{with} \mathrm{cell-cell} \mathrm{dissociation} \mathrm{(x100).} \mathrm{RON,} \mathrm{recepteur} \mathrm{d'origine} \mathrm{nantais;} \mathrm{MSP,} \mathrm{macrophage-stimulation}$ protein.

A

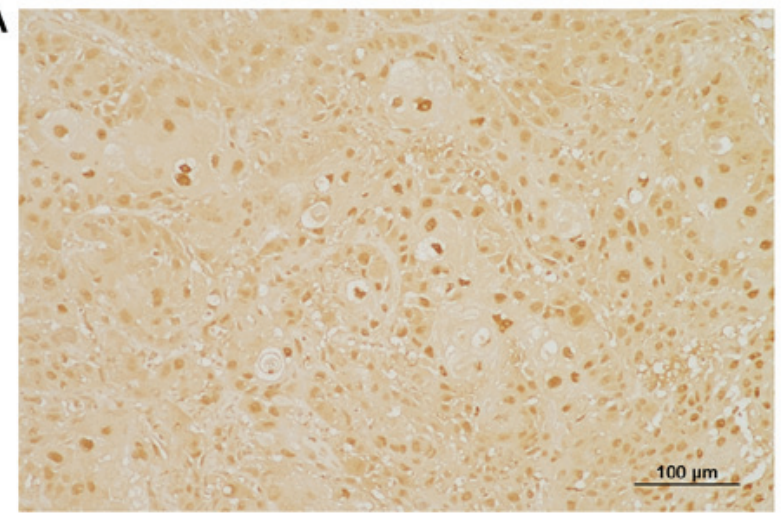

B

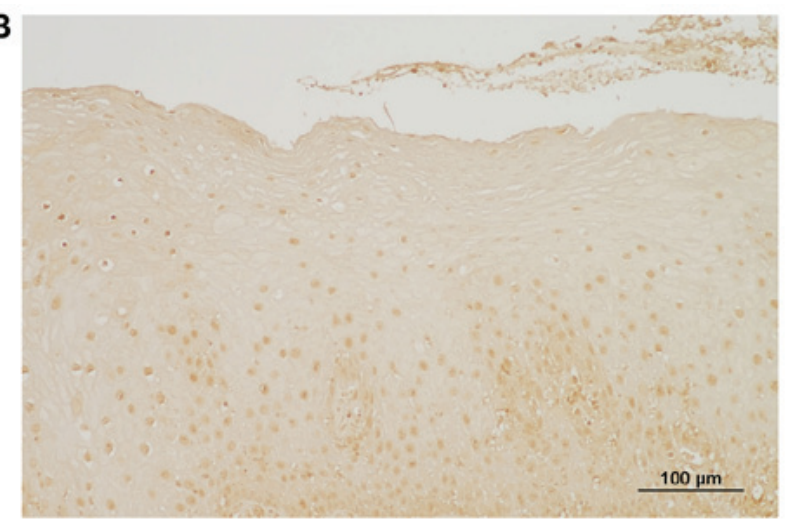

Figure 7. Protein expression of RON in human oral squamous cell carcinoma tissues. Immunostaining showed RON protein was increased in (A) cancer tissues compared with (B) adjacent tissue (x200). RON, recepteur d'origine nantais.

significant association was found between RON expression and DFS (P $>0.05$; Fig. 9).

To provide further support for the immunohistochemical data on RON protein expression, RON mRNA expression was analyzed using using RT-PCR and RT-qPCR in 20 fresh human OSCC tissue samples and paired normal oral mucosa samples. RON mRNA expression was significantly higher in OSCC tissue compared with paired normal oral tissue $(\mathrm{P}<0.01$; Fig. 10).

\section{Discussion}

OSCC typically has locoregional progression, and as it grows, it invades adjacent tissues and undergoes regional lymphatic metastasis, but rarely develops distant metastases (5). The depth of tumor invasion in OSCC is an important parameter for predicting lymphatic metastasis and patient survival (5). The depth of tumor invasion affects adjuvant treatment decisions, including the option of elective lymph node dissection. These are characteristics specific for OSCC, which differ from other types of head and neck cancers. Thus, the discovery of molecular targets involved in tumor invasion in OSCC patients is highly important.

RON is an attractive molecular target for OSCC therapy. In this study, RON knockdown reduced tumor cell invasion and migration. Conversely, RON activation by MSP, enhanced cell migration in human OSCC cells. Several previous studies support these findings. Maggiora et al (11) reported that overexpression of RON increased cell invasion and migration, and that MSP caused a 12-fold increase in migration of human breast carcinoma cells. In human colorectal cancer cells and hepatocellular cancer cells, RON knockdown suppresses tumor cell invasion and migration $(24,25)$. These findings suggest that RON-targeting therapy may control the invasiveness of cancer cells in OSCC.

RON has an important role in EMT. EMT has been highlighted as a key regulator of metastasis, by promoting tumor cell invasion. The EMT process is tightly controlled through a complex system of regulation of EMT-related transcription factors, such as Snail1, SLUG, Zeb1, Zeb2 and 
Table I. Association between RON expression and clinicopathological parameters in patients with oral squamous cell carcinoma.

\begin{tabular}{|c|c|c|c|c|}
\hline \multirow[b]{2}{*}{ Parameters } & \multirow[b]{2}{*}{$\begin{array}{c}\text { Total } \\
(n=89)\end{array}$} & \multicolumn{2}{|c|}{ RON expression } & \multirow[b]{2}{*}{ P-value } \\
\hline & & $\begin{array}{c}\text { Low } \\
(n=50)\end{array}$ & $\begin{array}{l}\text { High } \\
(n=39)\end{array}$ & \\
\hline Age (years) & & & & 0.21 \\
\hline$<62.7$ & 41 & 20 & 21 & \\
\hline$\geq 62.7$ & 48 & 30 & 18 & \\
\hline Sex & & & & 0.32 \\
\hline Male & 67 & 40 & 27 & \\
\hline Female & 22 & 10 & 12 & \\
\hline Location & & & & 0.11 \\
\hline Oral tongue & 61 & 38 & 23 & \\
\hline FOM, BM, RMT & 28 & 12 & 16 & \\
\hline Stage & & & & 1.00 \\
\hline I, II & 59 & 33 & 26 & \\
\hline III, IV & 30 & 17 & 13 & \\
\hline T stage & & & & 1.00 \\
\hline $\mathrm{T} 1, \mathrm{~T} 2$ & 79 & 44 & 35 & \\
\hline $\mathrm{T} 3, \mathrm{~T} 4$ & 10 & 6 & 4 & \\
\hline $\mathrm{N}$ stage & & & & 0.82 \\
\hline N0 & 63 & 36 & 27 & \\
\hline $\mathrm{N} 1, \mathrm{~N} 2$ & 26 & 14 & 12 & \\
\hline $\begin{array}{l}\text { Chemotherapy and/ } \\
\text { radiotherapy }\end{array}$ & & & & 1.00 \\
\hline No & 36 & 20 & 16 & \\
\hline Yes & 53 & 30 & 12 & \\
\hline Second primary & & & & \\
\hline malignancy & & & & 0.11 \\
\hline No & 61 & 38 & 23 & \\
\hline Yes & 28 & 12 & 16 & \\
\hline
\end{tabular}

$\chi^{2}$ test or Fisher's exact test was used. RON, recepteur d'origine nantais; FOM, floor of mouth; BM, buccal mucosa; RMT, retromolar trigone.

Twist1, which are responsible for inducing and sustaining the mesenchymal phenotype (26). Preliminary experiments were performed to determine the association between RON and various EMT-related transcription factors. Unfortunately, EMT-related factors, other than SLUG, showed variable results that were difficult to interpret among different cell line types, cell conditions and cell preparation timings. Additionally, it was difficult to obtain reproducibility in repeated experiments, even under the same conditions. Therefore, the experiments were focused on the association between RON and SLUG. RON activation by MSP induced cell morphological changes to spindle shape and RON knockdown suppressed SLUG expression. In addition, the promotion of cell invasion and migration by MSP-mediated RON activation was suppressed by $S L U G$ knockdown. These findings suggest that increased
Table II. Association between RON expression and recurrence/treatment failure in patients with oral squamous cell carcinoma.

\begin{tabular}{lcccc}
\hline & \multicolumn{4}{c}{ RON expression } \\
\cline { 3 - 4 } Parameters & $\begin{array}{c}\text { Total } \\
(\mathrm{n}=89)\end{array}$ & $\begin{array}{c}\text { Low } \\
(\mathrm{n}=50)\end{array}$ & $\begin{array}{c}\text { High } \\
(\mathrm{n}=39)\end{array}$ & P-value \\
\hline Recurrence & & & & 0.39 \\
$\quad$ No & $53(59.6 \%)$ & $32(64 \%)$ & $21(53.8 \%)$ & \\
$\quad$ Yes & $36(40.4 \%)$ & $18(36 \%)$ & $18(46.2 \%)$ & \\
Treatment & & & & 0.50 \\
failure & & & & \\
No & $59(66.3 \%)$ & $35(70 \%)$ & $24(61.5 \%)$ & \\
Yes & $30(33.7 \%)$ & $15(30 \%)$ & $15(38.5 \%)$ & \\
\hline
\end{tabular}

$\chi^{2}$ test and Fisher's exact test was used. RON, recepteur d'origine nantais.
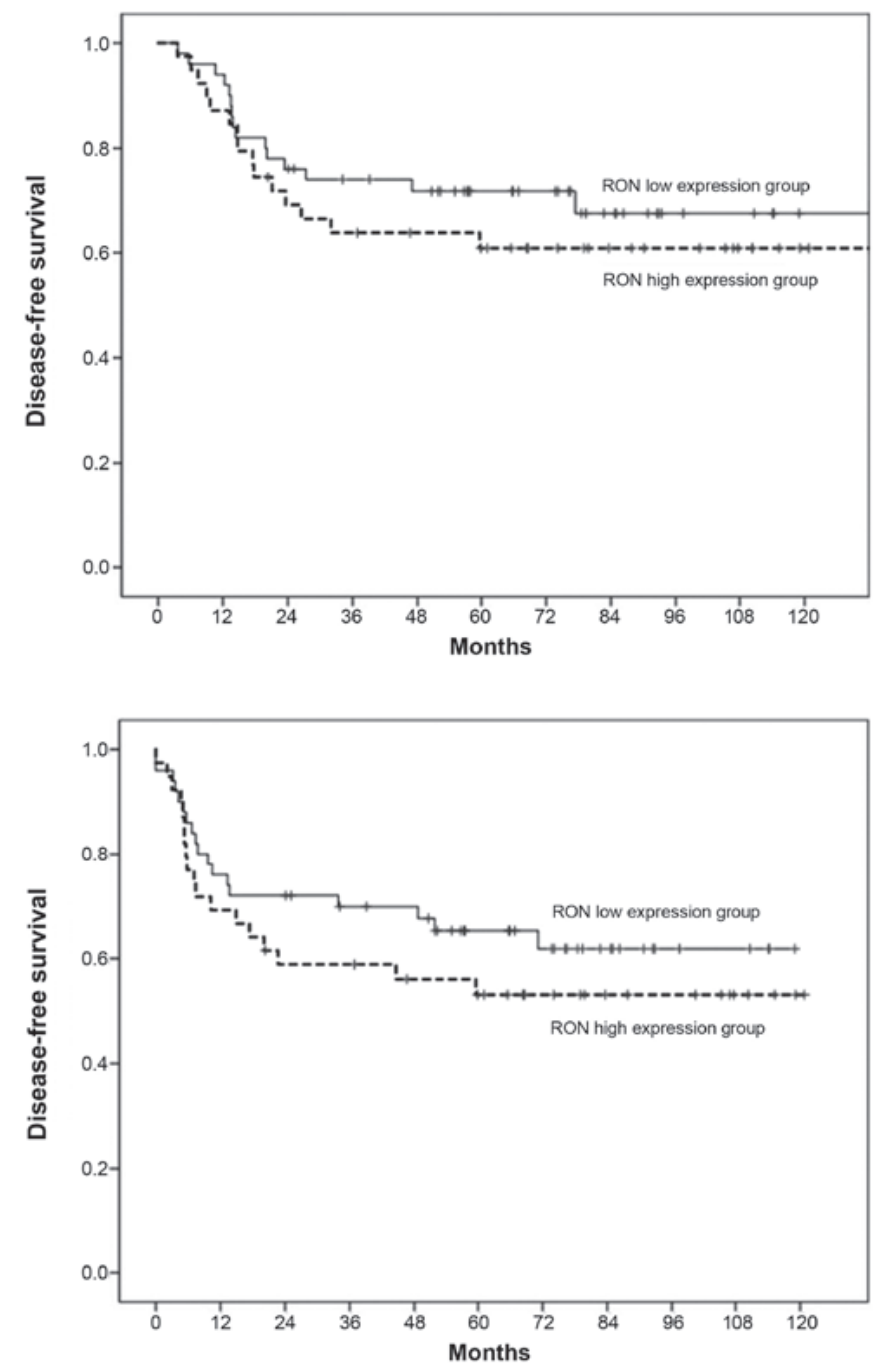

Figure 8. Kaplan-Meier curves of DSS and DFS for patients with OSCC by RON expression. RON expression did not correlate with DSS and DFS in patients with OSCC ( $n=89, P>0.05)$. Solid line, patients with low RON expression; dotted line, patients with high RON expression. DSS, disease-specific survival; DFS, disease-free survival; OSCC, oral squamous cell carcinoma; RON, recepteur d'origine nantais. 


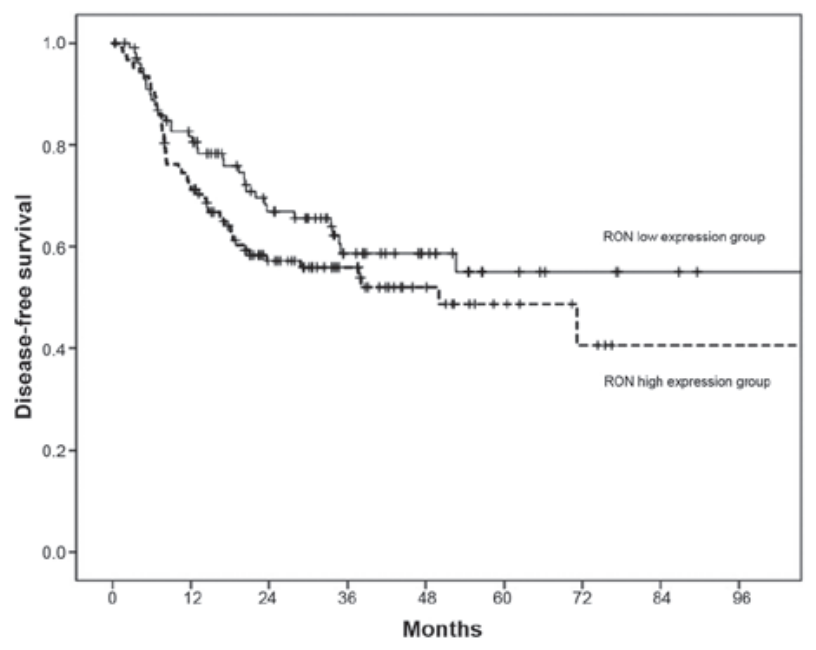

Figure 9. Kaplan-Meier curves of DFS for patients with OSCC by RON expression in a The Cancer Genome Atlas dataset. RON expression did not correlate with DFS in patients with OSCC $(n=226, P>0.05)$. Solid line: patients with low RON expression; dotted line: patients with high RON expression. DFS, disease-free survival; OSCC, oral squamous cell carcinoma; RON, recepteur d'origine nantais.
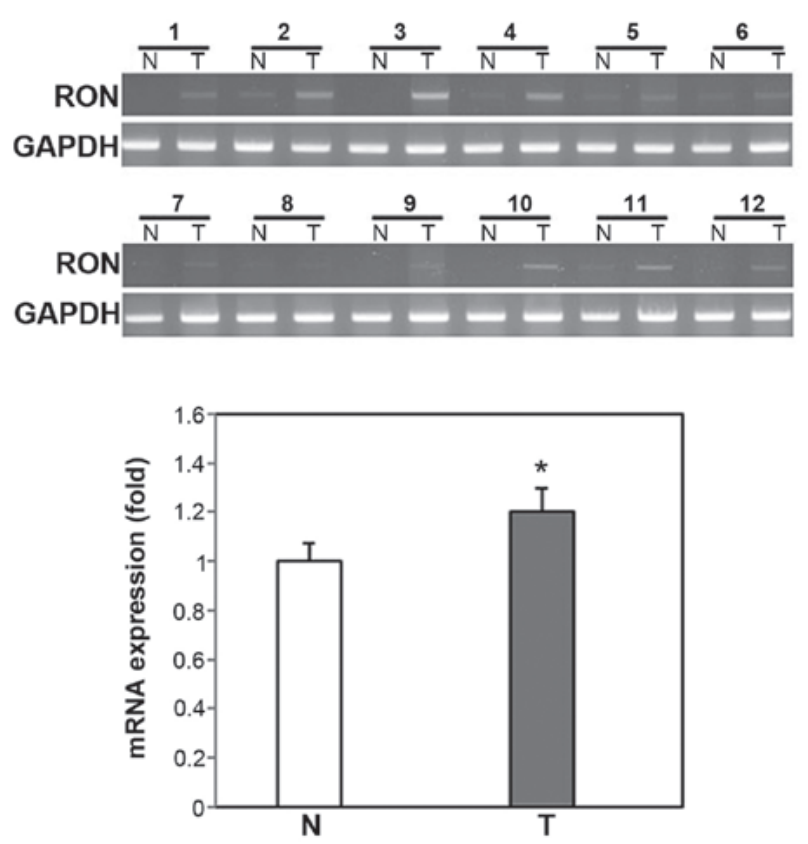

Figure 10. mRNA expression of RON in human OSCC fresh tissues. mRNA expression levels of RON were significantly higher in OSCC tissues, compared with normal oral tissues, as shown by RT-PCR (left panel) and RT-quantitative PCR (right panel) ( ${ }^{*} \mathrm{P}<0.01$ vs N). RT, reverse transcription; OSCC, oral squamous cell carcinoma; $\mathrm{N}$, normal oral tissues; $\mathrm{T}$, OSCC tissues; RON, recepteur d'origine nantais.

tumor cell invasion and migration by RON activation may be mediated by SLUG. The role of RON in EMT further supports the contribution of RON to tumor invasion and metastasis in OSCC.

The MAPK pathway, which includes ERK1/2, JNK and p38, plays a key role in various steps of cancer development (27). These proteins are involved in controlling cell proliferation, differentiation, migration and apoptosis in response to a variety of stresses, including cancers. In this study, RON knockdown suppressed the activation of ERK1/2, JNK and p38 in OSCC cells. In addition, $R O N$ knockdown was associated with the reversal of aggressive tumor cell behavior, such as apoptosis inhibition, cell invasion and cell migration in OSCC cells. Although additional evaluation may be required to clarify this mechanism, these findings suggested that RON knockdown inhibits aggressive tumor cell behavior by regulating the MAPK pathway in OSCC.

RON is involved in EMT through the MAPK pathway. Several studies have reported that RON activation induces spindle-shaped cell morphology and that RON is essential for the expression of a specialized mesenchymal marker (28-31). In addition, a MAPK inhibitor restored the original morphology of the epithelial cells or blocked the expression of EMT-related factors (28-30). These findings support the hypothesis that $\mathrm{RON}$ is associated with aggressive tumor cell behavior and is involved in EMT through the MAPK pathway in OSCC.

The abundant expression of a targeted molecule is the first requirement for an effective molecular target therapy. Elevated RON expression has been found to be associated with poor prognosis in multiple types of cancer, such as breast, stomach, colon, lung, bladder, ovary and cholangiocarcinoma $(14,15,32-36)$. It was also demonstrated that RON is overexpressed in both fresh OSCC tissue and paraffin-embedded tissue from human OSCC. However, contrary to expectations, there was no significant association between RON expression and prognostic indicators, including recurrence, treatment failure and survival in human OSCC. Although this is a limitation of our study, this is possible because the treatment outcomes of patients with cancer are affected by many factors, such as multiple genetic mutations, various other signaling pathways and specific microenvironments that contribute to cancer progression.

Several different splice variant isoforms of RON have been identified in several cancers (37-40). They are involved in RON activation in tumor cells and contribute to oncogenic activities (37). More importantly, efforts to block the RON activity, using low molecular weight kinase inhibitors or monoclonal antibodies, can be disrupted by unknown splice variants, because, despite having similar sequences, they exhibit different localizations and have varied functions (38). Thus, the influence of the RON splice variants needs to be considered when developing RON-targeting anticancer therapies.

$\mathrm{RON}$ is a promising target in various types of cancer. Many studies and clinical trials have been conducted to overcome cancer by inhibiting RON. The phase I/II clinical trials of the tyrosine kinase inhibitor, foretinib, multi-targeting c-Met, vascular endothelial growth factor 2 and RON, and anti-RON monoclonal antibody, narnatumab, have reported for advanced solid tumors, although the clinical trials were abandoned (21,41-43). Several studies recently reported that the anti-RON antibody $\mathrm{Zt} / \mathrm{g} 4$-drug conjugate (ADC) is effective in targeted inhibition of colorectal cancer, bladder cancer, triple-negative breast cancer and pancreatic cancer (44-47). In addition, Ruiz-Torres et al (48) demonstrated that the RON signaling pathway is associated with the immunosuppressive microenvironment in breast cancer. Ekiz et al (49) described that inhibition of RON kinase potentiates checkpoint immunotherapy in breast cancer. It is expected that the effectiveness of RON targeting anticancer therapy can be 
improved through the ADC technique and/or the combination therapy with immunotherapy.

In summary, RON knockdown suppressed cell invasion, migration and inhibition of apoptosis mediated by the MAPK pathway and the EMT-related factor, SLUG, in human OSCC cells. RON was overexpressed in human OSCC tissue. The results of the present study provide a theoretical basis for the application of RON-targeting agents, under active investigation, for the treatment of OSCC.

\section{Acknowledgements}

Not applicable.

\section{Funding}

This study was supported by a research grant from the Research Institute of Medical Sciences, Chonnam National University (2013-CURIMS-DR008).

\section{Availability of data and materials}

The datasets used and/or analyzed during the current study are available from the corresponding author on reasonable request.

\section{Author's contributions}

TMY and SAK analyzed the data and drafted manuscript. SAK performed the experimental study. DHL and JKL collected the clinical data. KHL analyzed the pathological data. TMY and YEJ participated in the design of the study. SCL, YEJ, IJC and MGN contributed to the interpretation of data. All authors read and approved the final manuscript.

\section{Ethics approval and consent to participate}

This study was approved by the ethics committee of the Institutional Review Board of Chonnam National University Hwasun Hospital (2011-027). Patients provided written informed consent for the use of resected tissue specimens.

\section{Patient consent for publication}

Not applicable

\section{Competing interests}

The authors declare that they have no competing interests.

\section{References}

1. Fitzmaurice C, Dicker D, Pain A, Hamavid H, Moradi-Lakeh M, MacIntyre MF, Allen C, Hansen G, Woodbrook R, Wolfe C, et al; Global Burden of Disease Cancer Collaboration: The global burden of cancer 2013. JAMA Oncol 1: 505-527, 2015.

2. Siegel R, Naishadham D and Jemal A: Cancer statistics, 2013. CA Cancer J Clin 63: 11-30, 2013.

3. Pfister DG, Spencer S, Adelstein D, Adkins D, Brizel DM, Burtness B, Busse PM, Caudell JJ, Cmelak AJ, Colevas AD, et al (eds): National Comprehensive Cancer Network: NCCN Clinical Practice Guidelines in Oncology (NCCN Guidelines) Head and Neck Cancers (Version 1), 2018. www.ncen. org. Accessed February 15, 2018.
4. Amin MB, Greene FL, Edge SB, Compton CC, Gershenwald JE, Brookland RK, Meyer L, Gress DM, Byrd DR and Wincheser DP (eds): American Joint Committee on Cancer-Cancer Staging Manual. 8th edition. Springer, New York, NY, 2018.

5. Pentenero M, Gandolfo S and Carrozzo M: Importance of tumor thickness and depth of invasion in nodal involvement and prognosis of oral squamous cell carcinoma: A review of the literature. Head Neck 27: 1080-1091, 2005.

6. Wang MH, Wang D and Chen YQ: Oncogenic and invasive potentials of human macrophage-stimulating protein receptor, the RON receptor tyrosine kinase. Carcinogenesis 24: 1291-1300, 2003.

7. Gaudino G, Follenzi A, Naldini L, Collesi C, Santoro M, Gallo KA, Godowski PJ and Comoglio PM: RON is a heterodimeric tyrosine kinase receptor activated by the HGF homologue MSP. EMBO J 13: 3524-3532, 1994.

8. Muraoka RS, Sun WY, Colbert MC, Waltz SE, Witte DP, Degen JL and Friezner Degen SJ: The Ron/STK receptor tyrosine kinase is essential for peri-implantation development in the mouse. J Clin Invest 103: 1277-1285, 1999.

9. Waltz SE, Eaton L, Toney-Earley K, Hess KA, Peace BE, Ihlendorf JR, Wang MH, Kaestner KH and Degen SJ: Ron-mediated cytoplasmic signaling is dispensable for viability but is required to limit inflammatory responses. J Clin Invest 108: 567-576, 2001 .

10. Chen Q, Seol DW, Carr B and Zarnegar R: Co-expression and regulation of Met and Ron proto-oncogenes in human hepatocellular carcinoma tissues and cell lines. Hepatology 26: 59-66, 1997.

11. Maggiora P, Marchio S, Stella MC, Giai M, Belfiore A, De Bortoli M, Di Renzo MF, Costantino A, Sismondi P and Comoglio PM: Overexpression of the RON gene in human breast carcinoma. Oncogene 16: 2927-2933, 1998.

12. Lin HS, Berry GJ, Fee WE Jr, Terris DJ and Sun Z: Identification of tyrosine kinases overexpressed in head and neck cancer. Arch Otolaryngol Head Neck Surg 130: 311-316, 2004.

13. Camp ER, Liu W, Fan F, Yang A, Somcio R and Ellis LM: RON, a tyrosine kinase receptor involved in tumor progression and metastasis. Ann Surg Oncol 12: 273-281, 2005.

14. Lee WY, Chen HH, Chow NH, Su WC, Lin PW and Guo HR: Prognostic significance of co-expression of RON and MET receptors in node-negative breast cancer patients. Clin Cancer Res 11: 2222-2228, 2005.

15. Cheng HL, Liu HS, Lin YJ, Chen HH, Hsu PY, Chang TY, Ho CL, Tzai TS and Chow NH: Co-expression of RON and MET is a prognostic indicator for patients with transitional-cell carcinoma of the bladder. Br J Cancer 92: 1906-1914, 2005.

16. Camp ER, Yang A, Gray MJ, Fan F, Hamilton SR, Evans DB, Hooper AT, Pereira DS, Hicklin DJ and Ellis LM: Tyrosine kinase receptor RON in human pancreatic cancer: Expression, function, and validation as a target. Cancer 109: 1030-1039, 2007.

17. Welm AL, Sneddon JB, Taylor C, Nuyten DS, van de Vijver MJ, Hasegawa BH and Bishop JM: The macrophage-stimulating protein pathway promotes metastasis in a mouse model for breast cancer and predicts poor prognosis in humans. Proc Natl Acad Sci USA 104: 7570-7575, 2007.

18. Catenacci DV, Cervantes G, Yala S, Nelson EA, El-Hashani E, Kanteti R, El Dinali M, Hasina R, Brägelmann J, Seiwert T, et al: RON (MST1R) is a novel prognostic marker and therapeutictarget for gastroesophageal adenocarcinoma. Cancer Biol Ther 12: 9-46, 2011.

19. Bieniasz M, Radhakrishnan P, Faham N, De La O JP and Welm AL: Preclinical efficacy of Ron kinase inhibitors alone and in combination with PI3K inhibitors for treatment of sfRon-expressing breast cancer patient-derived xenografts. Clin Cancer Res 21: 5588-5600, 2015.

20. Yao HP, Zhou YQ, Ma Q, Guin S, Padhye SS, Zhang RW and Wang MH: The monoclonal antibody $\mathrm{Zt} / \mathrm{f} 2$ targeting RON receptor tyrosine kinase as potential therapeutics against tumor growth-mediated by colon cancer cells. Mol Cancer 10: 82, 2011.

21. Shah MA, Wainberg ZA, Catenacci DV, Hochster HS, Ford J, Kunz P, Lee FC, Kallender H, Cecchi F, Rabe DC, et al: Phase II study evaluating 2 dosing schedules of oral foretinib (GSK1363089), cMET/VEGFR2 inhibitor, in patients with metastatic gastric cancer. PLoS One 8: e54014, 2013.

22. Yoon TM, Kim SA, Park YL, Lee KH, Sung MW, Lee JK, Lim SC, Chung IJ and Joo YE: Expression of the receptor tyrosine kinase recepteur d'origine nantais and its association with tumor progression in hypopharyngeal cancer. Head Neck 35: 1106-1113, 2013. 
23. Edge SB, Byrd DR, Compton CC, Fritz AG, Greene FL and Trotti A (eds): American Joint Committee on Cancer-Cancer Staging Manual. 7th edition. Springer, New York, NY, 2010.

24. Xu XM, Wang D, Shen Q, Chen YQ and Wang MH: RNA-mediated gene silencing of the RON receptor tyrosine kinase alters oncogenic phenotypes of human colorectal carcinoma cells. Oncogene 23: 8464-8474, 2004.

25. Cho SB, Park YL, Song YA, Kim KY, Lee GH, Cho DH, Myung DS, Park KJ, Lee WS, Chung IJ, et al: Small interfering RNA-directed targeting of RON alters invasive and oncogenic phenotypes of human hepatocellular carcinoma cells. Oncol Rep 26: 1581-1586, 2011.

26. Santamaria PG, Moreno-Bueno G, Portillo F and Cano A: EMT: Present and future in clinical oncology. Mol Oncol 11: 718-738, 2017.

27. Wagner EF and Nebreda AR: Signal integration by JNK and p38 MAPK pathways in cancer development. Nat Rev Cancer 9: 537-549, 2009.

28. Wang D, Shen Q, Chen YQ and Wang MH: Collaborative activities of macrophage-stimulating protein and transforming growth factor-betal in induction of epithelial to mesenchymal transition: Roles of the RON receptor tyrosine kinase. Oncogene 23: 1668-1680, 2004.

29. Xiangming X, Yun Q, Guoliang Z, Jianjiang L and Lisong T: Mechanisms of RON-mediated epithelial-mesenchymal transition in MDCK cells through the MAPK pathway. Braz J Med Biol Res 44: 634-641, 2011 .

30. Wang D, Shen Q, Xu XM, Chen YQ and Wang MH: Activation of the RON receptor tyrosine kinase attenuates transforming growth factor-betal-induced apoptotic death and promotes phenotypic changes in mouse intestinal epithelial cells. Carcinogenesis 26: 27-36, 2005.

31. Côté M, Miller AD and Liu SL: Human RON receptor tyrosine kinase induces complete epithelial-to-mesenchymal transition but causes cellular senescence. Biochem Biophys Res Commun 360: 219-225, 2007.

32. Lee CT, Chow NH, Su PF, Lin SC, Lin PC and Lee JC: The prognostic significance of RON and MET receptor coexpression in patients with colorectal cancer. Dis Colon Rectum 51: 1268-1274, 2008.

33. Song YA, Park YL, Kim KY, Myung E, Chung CY, Cho SB, Lee WS, Jung YD, Kweon SS and Joo YE: RON is associated with tumor progression via the inhibition of apoptosis and cell cycle arrest in human gastric cancer. Pathol Int 62: 127-136, 2012.

34. Han WL, Li WD, Hu J, Rusidanmu A, Chen LF, Shen L and Zheng SS: Expression of the recepteur d'originenantais receptor tyrosine kinase in non-small cell lung cancer and its clinical significance. Chin Med J (Engl) 125: 1110-1114, 2012.

35. Ferrandina G, Martinelli E, Petrillo M, Prisco MG, Zucconi A, Santaguida S, Zannoni G, Scambia G and Ferlini C: Prognostic role of the recepteur d'origine nantais (RON) expression in ovarian cancer patients. Gynecol Oncol 111: 237-243, 2008.

36. Cheng CT, Chen YY, Wu RC, Tsai CY, Chiang KC, Yeh TS, Chen MH and Yeh CN: MET-RON dual inhibitor, BMS-777607, suppresses cholangiocarcinoma cell growth, and MET-RON upregulation indicates worse prognosis for intra-hepatic cholangiocarcinoma patients. Oncol Rep 40: 1411-1421, 2018.

37. Ling Y, Kuang Y, Chen LL, Lao WF, Zhu YR, Wang LQ and Wang D: A novel RON splice variant lacking exon 2 activates the PI3K/AKT pathway via PTEN phosphorylation in colorectal carcinoma cells. Oncotarget 8: 39101-39116, 2017.
38. Krishnaswamy S, Mohammed AK, Tripathi G, Alokail MS and Al-Daghri NM: Splice variants of the extracellular region of RON receptor tyrosine kinase in lung cancer cell lines identified by PCR and sequencing. BMC Cancer 17: 738, 2017.

39. Chakedis J, French R, Babicky M, Jaquish D, Howard H, Mose E, Lam R, Holman P, Miyamoto J, Walterscheid Z, et al: A novel protein isoform of the RON tyrosine kinase receptor transforms human pancreatic duct epithelial cells. Oncogene 35: 3249-3259, 2016.

40. Krishnaswamy S, Bukhari I, Mohammed AK, Amer OE, Tripathi G, Alokail MS and Al-Daghri NM: Identification of the splice variants of Recepteur d'Origine nantais (RON) in lung cancer cell lines. Gene 679: 335-340, 2018.

41. Leighl NB, Tsao MS, Liu G, Tu D, Ho C, Shepherd FA, Murray N, Goffin JR, Nicholas G, Sakashita S, et al: A phase I study of foretinib plus erlotinib in patients with previously treated advanced non-small cell lung cancer: Canadian cancer trials group IND.196. Oncotarget 8: 69651-69662, 2017

42. Yau TCC, Lencioni R, Sukeepaisarnjaroen W, Chao Y, Yen CJ, Lausoontornsiri W, Chen PJ, Sanpajit T, Camp A, Cox DS, et al: A phase I/II multicenter study of single-agent foretinib as first-line therapy in patients with advanced hepatocellular carcinoma. Clin Cancer Res 23: 2405-2413, 2017.

43. LoRusso PM, Gounder M, Jalal SI, André V, Kambhampati SRP, Loizos N, Hall J, Holzer TR, Nasir A, Cosaert J, et al: Phase 1 study of narnatumab, an anti-RON receptor monoclonal antibody, in patients with advanced solid tumors. Invest New Drugs 35: 442-450, 2017.

44. Feng L, Yao HP, Wang W, Zhou YQ, Zhou J, Zhang R and Wang MH: Efficacy of anti-RON antibody Zt/g4-drug maytansinoid conjugation (anti-RON ADC) as a novel therapeutics for targeted colorectal cancer therapy. Clin Cancer Res 20: 6045-6058, 2014.

45. Chen JF, Yu BX, Yu R, Ma L, Lv XY, Cheng Y and Ma Q: Monoclonal antibody $\mathrm{Zt} / \mathrm{g} 4$ targeting RON receptor tyrosine kinase enhances chemosensitivity of bladder cancer cells to Epirubicin by promoting G1/S arrest and apoptosis. Oncol Rep 37: 721-728, 2017.

46. Suthe SR, Yao HP, Weng TH, Hu CY, Feng L, Wu ZG and Wang MH: RON receptor tyrosine kinase as a therapeutic target for eradication of triple-negative breast cancer: Efficacy of anti-RON ADC Zt/g4-MMAE. Mol Cancer Ther 17: 2654-2664, 2018.

47. Yao HP, Feng L, Weng TH, Hu CY, Suthe SR, Mostofa AGM, Chen LH, Wu ZG, Wang WL and Wang MH: Preclinical efficacy of anti-RON antibody-drug conjugate Zt/g4-MMAE for targeted therapy of pancreatic cancer overexpressing RON receptor tyrosine kinase. Mol Pharm 15: 3260-3271, 2018.

48. Ruiz-Torres SJ, Benight NM, Karns RA, Lower EE, Guan JL and Waltz SE: HGFL-mediated RON signaling supports breast cancer stem cell phenotypes via activation of non-canonical $\beta$-catenin signaling. Oncotarget 8: 58918-58933, 2017.

49. Ekiz HA, Lai SA, Gundlapalli H, Haroun F, Williams MA and Welm AL: Inhibition of RON kinase potentiates anti-CTLA-4 immunotherapy to shrink breast tumors and prevent metastatic outgrowth. Oncoimmunology 7: e1480286, 2018. 